\title{
Synthesis, stability and spectral behavior of fluorogenic sulfone-pyronin and sulfone-rosamine dyes
}

\author{
Garance Dejouy ${ }^{\mathrm{a}}$, Myriam Laly ${ }^{\mathrm{a}}$, Ibai E. Valverde ${ }^{\mathrm{a}}$, Anthony Romieu, ${ }^{\mathrm{a}, \mathrm{b},{ }^{*}}$ \\ ${ }^{a}$ Institut de Chimie Moléculaire de l'Université de Bourgogne, UMR 6302, CNRS, Univ. Bourgogne Franche- \\ Comté, 9, Avenue Alain Savary, 21078 Dijon cedex, France \\ ${ }^{b}$ Institut Universitaire de France, 1, Rue Descartes, Bâtiment MONGE, 75231 Paris, France
}

\begin{abstract}
The first synthesis of sulfone-pyronin and sulfone-rosamine dyes bearing optically tunable primary amino groups (acting as fluorogenic centers) is presented. Sulfone analogs of xanthene-based fluorophores have recently been highlighted as a new class of near-infrared (NIR) fluorescent dyes (Liu et al. ACS Appl Mater Interfaces 2016;8(35):22953-62), and the availability of fluorogenic derivatives is essential for the rapid construction of "turn-on" reactive probes for chemoselective bioimaging. However, these fluorescent anilines have been found to be unstable in aqueous physiological conditions due to the marked electrophilicity of their meso-position and hence its propensity to undergo nucleophilic attack by a water molecule or a hydroxyde anion. Further investigations have helped us to determine the acidic $\mathrm{pH}$ range at which the sulfone-rosamine $\mathbf{2}$ is fully-stable and a complete assessment of the photophysical properties could be performed. Its pro-fluorescent character and utility were then proved by the preparation and in vitro enzymatic activation of a penicillin $G$ acylase (PGA) sensitive fluorogenic probe.
\end{abstract}

\section{Graphical abstract}

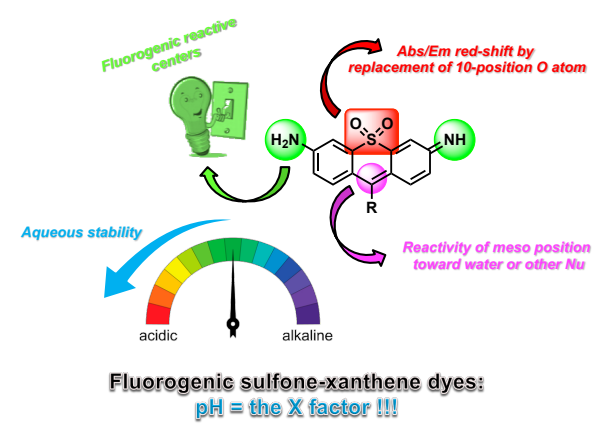

Keywords Fluorogenic enzyme substrate, Hetero-xanthene dye, NIR dye, Pyronin, Rosamine

\section{Highlights}

Synthesis of first near-infrared fluorogenic sulfone-rosamine dye Aqueous stability of fluorogenic sulfone rosamine dye only at $\mathrm{pH}<3.5$

A novel fluorogenic probe for detection of PGA working in acidic buffer conditions The PGA-sensitive probe acts as a "AND" fluorescent molecular logic gate Complete hydration of sulfone-pyronin dyes in aqueous media whatever the $\mathrm{pH}$ value

\footnotetext{
* Corresponding author. Tel. +33 3-80-39-36-24 ; e-mail anthony.romieu@u-bourgogne.fr
} 


\section{Introduction}

Rhodamines and related xanthene dyes (i.e., pyronins, rhodols, and rosamines) are popular visible-wavelength fluorophoresas evidenced by their heavy use as optically active reporters in a myriad of applications, particularly in the fields of bioanalysis and bioimaging[1-3]. This broad utility stems from several unique and valuable features inherent in these fluorescent molecules: (1) good to high brightness in both organic solvents and aqueous media often associated with a marked photostability, (2) remarkable chemical stability under harsh conditions of $\mathrm{pH}$ and temperature and toward various chemical reagents, (3) cationic character favoring water solubility and cell membrane permeability, and (4) easy modulation of the fluorescence properties through the reversible spirocycle ring-opening process and/or through the protection-deprotection of amino groups[4-7]. Thus, a myriad of fluorescent labeling reagents for biomolecules[8] as well as a huge number of activatable (or "smart") fluorescent probes for analyte sensing/imaging based on a rhodamine (or pyronin/rhodol/rosamine) scaffold have been developed. Some of them have had a major impact in modern biochemical/biological research[4,5,9], leading sometimes to commercial successes (e.g., dyes belonging to the Alexa Fluor $^{\circledR}$ family ranging from Alexa Fluor ${ }^{\circledR} 488$ to Alexa Fluor ${ }^{\circledR} 635[10$ 12], rhodamine 110-based fluorogenic enzyme substrates[13,14], ...). To achieve sensitive and reliable fluorescence detection in complex biological systems or in living organisms, and thus considering biomedical applications for xanthene-based fluorophores, current research efforts are primarily devoted to the design of rhodamines and related compounds having absorption/emission maxima in the spectral range 650-900 $\mathrm{nm}[15]$, often called "therapeutic optical window" (or NIR-1 window)[16]. The relevant strategies implemented to achieve this goal can be classified into two main categories: (1) the extension of the $\pi$-conjugated system either through the introduction of various fused aromatic rings within the xanthene core[1730] or the installation of a dimethine bridge connecting another chromophore unit (e.g., dihydroxanthene-hemicyanine fused dyes)[31,32], and (2) the replacement of the 10-position $\mathrm{O}$ atom of xanthene by a group 14 element (i.e., $\mathrm{C}, \mathrm{Si}$, or $\mathrm{Ge}$ )[33-36] or an oxidized- heteroatom such as $\mathrm{B}(\mathrm{OH})_{2}[37], \mathrm{P}(\mathrm{O}) \mathrm{R}[38,39], \mathrm{P}(\mathrm{O}) \mathrm{OR}[40]$, or $\mathrm{Te}(\mathrm{O})[41]$. This latter approach is particularly attractive because it produces dyes with significantly red-shifted absorption and fluorescence maxima, typically around or above $650 \mathrm{~nm}$, and keeping compact structures and small molecular weights. A further extension of this strategy to $\mathrm{Bi}[42], \mathrm{S}$, and $\mathrm{Se}[43]$ leads to weakly or non-fluorescent heteroatom-substituted xanthene dyes usable as effective photosensitizers in photodynamic therapy of cancers. In addition, a recent work from Liu et al. 
related to the synthesis and photophysical characterization of sulfone-rhodamines and sulfonerosamines grabbed your attention[44]. Indeed, these hetero-xanthene dyes show absorption/emission features in the range $700-750 \mathrm{~nm}$, with satisfactory fluorescence quantum yields $(5-10 \%)$ in simulated physiological conditions (i.e., phosphate-buffered saline (PBS), $20 \mathrm{mM}, \mathrm{pH} 7.4$, containing $0.25 \% \mathrm{CH}_{3} \mathrm{CN}$ ). However, since all these compounds are tetramethylrosamine or tetramethylrhodamine (TMR) analogs, they do not possess an optically tunable primary or secondary amino group for an effective modulation of their fluorescence properties. This aniline substitution pattern prevents their use as fluorescent platforms for developing reaction-based probes for chemoselective sensing/imaging of enzymes, small molecules and metal ions in biological systems[45,46]. To address this problem, we considered the synthesis of sulfone-pyronin and sulfone-rosamine derivatives, through the formal substitution $\mathrm{O} \rightarrow \mathrm{SO}_{2}$ in 6-amino-3H-xanthen-3-imine and 6-amino-9-aryl-3H-xanthen-3-imine core structures respectively (Fig. 1 and 2).<smiles>N=c1ccc2cc3ccc(N)cc3oc-2c1</smiles>

6-Amino-3H-xanthen-3-imine<smiles>[X]c1ccc2cc3ccc(N(C)C)cc3cc2[Y]1=[N+](C)C</smiles>

Pyronin $Y, Y=O$ TMDHS, $Y=\mathrm{SiMe}_{2}$
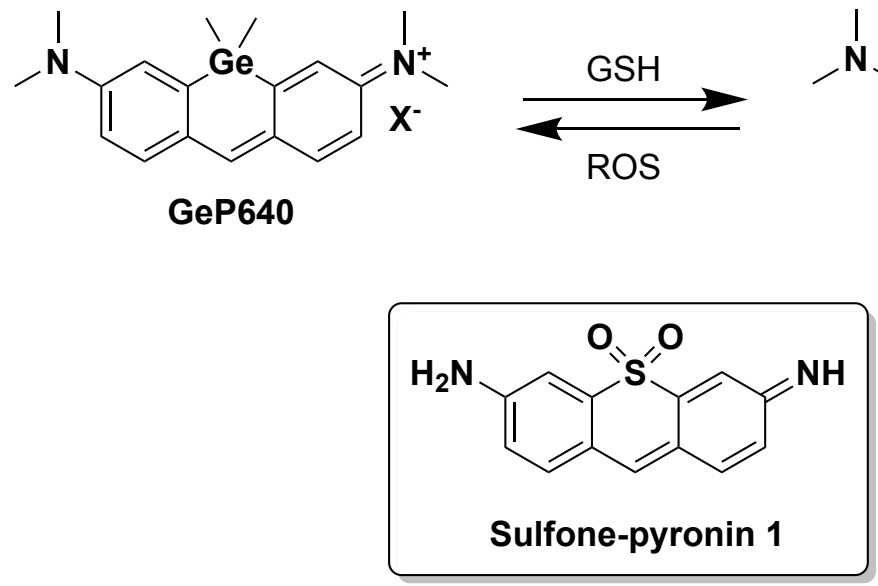<smiles>CN(C)c1ccc2c(c1)C(C)(C)c1ccc(N(C)C)cc1C2(C)[SeH]</smiles>

GeP640-SG

Fig. 1. Structures of already known pyronins and fluorogenic sulfone-pyronin dye 1 studied in this work $\left(\mathrm{X}=\mathrm{Cl}^{-}\right.$ for pyronin $\mathrm{Y}$ and TMDHS, $\mathrm{X}^{-}=\mathrm{CF}_{3} \mathrm{CO}_{2}^{-}$for GeP640, $\mathrm{GSH}=$ glutathione, $\mathrm{ROS}=$ reactive oxygen species).

Indeed, the installation of primary amino groups imparts a powerful fluorescence "ON-OFF" switching mechanism based on a protection-deprotection strategy to these NIR dyes[6]. The straightforward access to efficient small-molecule fluorogenic probes for in vivo molecular imaging of disease-related enzymes (mainly, proteases)[47-51], should, therefore, be facilitated using these fluorescent anilines. In this Article, we report the first results of this 
ambitious project, through the preparation and spectral characterization of two original fluorogenic sulfone-xanthene dyes. Emphasis will also be put on the $\mathrm{pH}$-dependent stability of these compounds that has never been reported to date. Finally, in order to demonstrate the fluorogenic behavior of this novel class of "smart" NIR dyes, an enzyme-responsive "turn-on" fluorescent probe selectively activated by penicillin $\mathrm{G}$ acylase has been synthesized and validated through in vitro fluorescence assay.<smiles>Cc1ccccc1-c1c2ccc(=N)cc-2oc2cc(N)ccc12</smiles>

2Me RG<smiles>[X]c1ccc2c(c1)S(=O)(=O)c1cc(N(C)C)ccc1C2c1ccccc1C</smiles>

$\mathrm{SO}_{2} \mathrm{R2}$<smiles>Cc1ccccc1C1=C2C=CC(=N)C=C2S(=O)(=O)c2cc(N)ccc21</smiles>

Fig. 2. Structures of already known rosamines and fluorogenic sulfone-rosamine dye 2 studied in this work $\left(\mathrm{X}^{-}=\right.$ $\mathrm{Cl}^{-}$for $\mathrm{SO}_{2} \mathbf{R 2}$ ).

\section{Experimental}

\subsection{Chemicals and Instruments}

Unless noted otherwise, all commercially available reagents and solvents were used without further purification. TLC were carried out on Merck DC Kieselgel 60 F-254 aluminum sheets. The spots were directly visualized or through illumination with a UV lamp $(\lambda=254 / 365 \mathrm{~nm})$. Column chromatography purifications were performed manually either on silica gel (40-63 $\mu \mathrm{m}$ or 63-200 $\mu \mathrm{m}$ ) from Sigma-Aldrich (technical grade) or Geduran ${ }^{\circledR}$ Si 60 silica gel (40-63 $\left.\mu \mathrm{m}\right)$ from Merck Millipore. Some chromatographic purifications were performed using an automated flash chromatography purification system (Interchim puriFlash ${ }^{\mathrm{TM}}$ 430) with puriFlash ${ }^{\mathrm{TM}}$ columns (silica gel, $25 \mu \mathrm{m}$ ). THF and $\mathrm{CH}_{3} \mathrm{CN}$ (HPLC-grade) were dried over alumina cartridges using a solvent purification system PureSolv PS-MD-5 model from 
Innovative Technology. Anhydrous $\mathrm{C}_{2} \mathrm{H}_{4} \mathrm{Cl}_{2}$ was purchased from Sigma-Aldrich. Peptide synthesis-grade DIEA and TFA were provided by Iris Biotech GmbH. The HPLC-gradient grade $\mathrm{CH}_{3} \mathrm{CN}$ used for HPLC-MS analyses was obtained from Carlo Erba. $\mathrm{CH}_{3} \mathrm{CN}$ used in semi-preparative RP-HPLC purifications was obtained from Biosolve or VWR (technical, $+99 \%$ but distilled prior to use). All aq. buffers used in this work and aq. mobile-phases for HPLC were prepared using water purified with a PURELAB Ultra system from ELGA (purified to $18.2 \mathrm{M} \Omega . \mathrm{cm}$ ). Penicillin G acylase (PGA, from Escherichia coli) was provided by Iris Biotech GmbH. n-Butyllithium (BuLi) solution (in hexanes, Acros) was titrated before using (colorimetric titration with menthol $+2,2$-bipyridine or 2,2-diphenylacetic acid in dry THF)[52,53] and 2-bromotoluene was distilled prior to use.

\subsection{Instruments and methods}

Lyophilization steps were performed with a Christ Alpha 2-4 LD plus. ${ }^{1} \mathrm{H}-,{ }^{13} \mathrm{C}$ - and ${ }^{19} \mathrm{~F}$ NMR spectra were recorded either on a Bruker Avance III $500 \mathrm{MHz}$ or on a Bruker Avance III HD $600 \mathrm{MHz}$ spectrometer (equipped with double resonance broad band probes). Chemical shifts are expressed in parts per million ( $\mathrm{ppm}$ ) from the residual non-deuterated solvent signal[54]. $J$ values are expressed in Hz. IR spectra were recorded with a Bruker Alpha FT-IR spectrometer equipped with a universal ATR sampling accessory. The bond vibration frequencies are expressed in reciprocal centimeters $\left(\mathrm{cm}^{-1}\right)$. Elemental analyses $(\mathrm{C}, \mathrm{H}, \mathrm{N}, \mathrm{S})$ were performed on a Thermo Scientific Flash EA 1112 instrument. HPLC-MS analyses were performed on a Thermo-Dionex Ultimate 3000 instrument (pump + autosampler at $20{ }^{\circ} \mathrm{C}+$ column oven at $25{ }^{\circ} \mathrm{C}$ ) equipped with a diode array detector (Thermo-Dionex DAD 3000-RS) and a MSQ Plus single quadrupole mass spectrometer. HPLC-fluorescence analyses were performed with the same instrument coupled to a RS fluorescence detector (Thermo-Dionex, FLD 3400-RS). Purifications by semi-preparative HPLC were performed on a Thermo-Dionex Ultimate 3000 instrument equipped with a RS Variable Detector (four distinct wavelengths). Ion chromatography analyses were performed using an ion chromatograph Thermo Scientific Dionex ICS 5000 equipped with a conductivity detector CD (Thermo Scientific Dionex) and a conductivity suppressor ASRS-ultra II 4 mm (Thermo Scientific Dionex). Low-resolution mass spectra (LRMS) were recorded on a Thermo Scientific MSQ Plus single quadrupole equipped with an electrospray (ESI) source (direct introduction or LC-MS coupling). UV-visible spectra were obtained either on a Varian Cary 50 scan (single-beam) or an Agilent Cary 5000 UV-VISNIR (double beam) spectrophotometer by using a rectangular quartz cell (Hellma, 100-QS, 45 
$\times 12.5 \times 12.5 \mathrm{~mm}$, pathlength: $10 \mathrm{~mm}$, chamber volume: $3.5 \mathrm{~mL}$ ), at $25^{\circ} \mathrm{C}$ (using a temperature control system combined with water circulation). Fluorescence spectroscopic studies (scan and kinetics modes) were performed with an HORIBA Jobin Yvon Fluorolog spectrofluorometer (software FluorEssence) at $25 / 37^{\circ} \mathrm{C}$ (using a temperature control system combined with water circulation), with a standard fluorometer cell (Labbox, LB Q, light path: $10 \mathrm{~mm}$, width:10 mm, chamber volume: $3.5 \mathrm{~mL}$ ). The absorption spectra of sulfone-xanthene dyes were recorded (220-800 $\mathrm{nm}$ ) in the corresponding solvent with concentrations in the range 10-50 $\mu \mathrm{M}$. Excitation/emission spectra were recorded after emission/excitation at the suitable wavelength (see Table 1, shutter: Auto Open, excitation slit $=5 \mathrm{~nm}$ and emission slit $=5 \mathrm{~nm}$ ). All fluorescence spectra were corrected. Fluorescence quantum yields were measured at $25{ }^{\circ} \mathrm{C}$ by a relative method using the suitable standard (see Table 1, dilution by a factor of 3 between absorption and fluorescence measurements). The following equation was used:

$$
\Phi_{\mathrm{F}}(\mathrm{x})=\left(\mathrm{A}_{\mathrm{S}} / \mathrm{A}_{\mathrm{X}}\right)\left(\mathrm{F}_{\mathrm{X}} / \mathrm{F}_{\mathrm{S}}\right)\left(\mathrm{n}_{\mathrm{X}} / \mathrm{n}_{\mathrm{S}}\right)^{2} \Phi_{\mathrm{F}}(\mathrm{s})
$$

where $\mathrm{A}$ is the absorbance (in the range of 0.01-0.1 A.U.), $\mathrm{F}$ is the area under the emission curve, $\mathrm{n}$ is the refractive index of the solvents (at $25^{\circ} \mathrm{C}$ ) used in measurements, and the subscripts $\mathrm{s}$ and $\mathrm{x}$ represent standard and unknown, respectively.

Table 1. Experimental conditions used for the determination of fluorescence quantum yields.

\begin{tabular}{|c|c|c|c|c|c|}
\hline Fluorophore $^{a}$ & Solvent & $\lambda \operatorname{Ex}(\mathrm{nm})$ & Standard (std) & $\Phi_{\mathrm{F}(\mathrm{std})} /$ solvent & $\Phi_{\mathrm{F}}$ \\
\hline 1 & $\begin{array}{c}\mathrm{CH}_{3} \mathrm{CN}+ \\
10 \% \\
\mathrm{TFA}^{b}\end{array}$ & 580 & Сy 5.0[55] & $0.2 / \mathrm{PBS}^{c}$ & 0.14 \\
\hline 2 & $\begin{array}{c}\mathrm{H}_{2} \mathrm{O}+ \\
0.1 \% \mathrm{FA}^{d}\end{array}$ & 600 & Сy 5.0[55] & $0.2 / \mathrm{PBS}^{c}$ & 0.06 \\
\hline
\end{tabular}

\subsection{High-performance liquid chromatography separations}

Several chromatographic systems were used for the analytical experiments and purification steps: System A: RP-HPLC-MS (Phenomenex Kinetex $\mathrm{C}_{18}$ column, $2.6 \mu \mathrm{m}, 2.1 \times 50 \mathrm{~mm}$ ) with $\mathrm{CH}_{3} \mathrm{CN}(+0.1 \% \mathrm{FA})$ and $0.1 \%$ aq. formic acid (aq. FA, $\left.\mathrm{pH} 2.5\right)$ as eluents $\left[2 \% \mathrm{CH}_{3} \mathrm{CN}(0.1\right.$ 
min) followed by a linear gradient from $2 \%$ to $100 \%$ (5 min) of $\mathrm{CH}_{3} \mathrm{CN}$, then $100 \% \mathrm{CH}_{3} \mathrm{CN}$ $(1.5 \mathrm{~min})]$ at a flow rate of $0.5 \mathrm{~mL} / \mathrm{min}$. Quadruple UV-visible detection was achieved at 220, 260, 600 and $700 \mathrm{~nm}$ (+ diode array detection in the range 200-800 nm). LR ESI-MS detection in the positive/negative mode (full scan, 100-2000 a.m.u., peaking format: centroid, needle voltage: $3.0 \mathrm{kV}$, probe temperature: $350^{\circ} \mathrm{C}$, cone voltage: $75 \mathrm{~V}$ and scan time: $1 \mathrm{~s}$.) System B: system A with the following gradient $\left[50 \% \mathrm{CH}_{3} \mathrm{CN}(0.1 \mathrm{~min})\right.$ followed by a linear gradient from $50 \%$ to $100 \%$ (6.5 min) of $\mathrm{CH}_{3} \mathrm{CN}$, then $100 \% \mathrm{CH}_{3} \mathrm{CN}$ (0.5 min)]. Quadruple UV-visible detection was achieved at 220, 300, 650 and $700 \mathrm{~nm}$. System C: semi-preparative RP-HPLC (SiliCycle SiliaChrom $\mathrm{C}_{18}$ column, $10 \mu \mathrm{m}, 20 \times 250 \mathrm{~mm}$ ) with $\mathrm{CH}_{3} \mathrm{CN}$ and $0.1 \%$ aq. TFA as eluents $\left[0 \% \mathrm{CH}_{3} \mathrm{CN}\right.$ (5 min), followed by a linear gradient from $0 \%$ to $10 \%$ (4 $\mathrm{min}$ ) and 10\% to $100 \%$ (90 $\mathrm{min}$ ) of $\mathrm{CH}_{3} \mathrm{CN}$ ] at a flow rate of $20.0 \mathrm{~mL} / \mathrm{min}$. Quadruple UV-visible detection was achieved at 220, 300, 310 and $640 \mathrm{~nm}$. System D: system C with the following gradient [10\% $\mathrm{CH}_{3} \mathrm{CN}$ (5 min), followed by a linear gradient from $10 \%$ to $15 \%$ (2.5 min) and $15 \%$ to $100 \%$ (170 min) of $\mathrm{CH}_{3} \mathrm{CN}$ ]. Quadruple UV-Vis detection was achieved at 220, 240, 490 and $640 \mathrm{~nm}$. System E: semi-preparative RP-HPLC (Thermo Hypersil GOLD C ${ }_{18}$ column, $5 \mu \mathrm{m}, 10$ $\times 250 \mathrm{~mm}$ ) with $\mathrm{CH}_{3} \mathrm{CN}$ and $0.1 \%$ aq. TFA as eluents [0\% $\mathrm{CH}_{3} \mathrm{CN}$ (5 min), followed by a linear gradient from $0 \%$ to $10 \%(5 \mathrm{~min})$ and $10 \%$ to $100 \%$ (90 $\mathrm{min}$ ) of $\mathrm{CH}_{3} \mathrm{CN}$ ] at a flow rate of 4.0 $\mathrm{mL} / \mathrm{min}$. Quadruple UV-Vis detection was achieved at 220, 260, 490 and $645 \mathrm{~nm}$. System F: system A with the following gradient $\left[5 \% \mathrm{CH}_{3} \mathrm{CN}(0.1 \mathrm{~min})\right.$ followed by linear gradient from $5 \%$ to $100 \%$ (6.5 min) of $\mathrm{CH}_{3} \mathrm{CN}$, then $100 \% \mathrm{CH}_{3} \mathrm{CN}$ (1 min)]. Quadruple UV-visible detection was achieved at 220, 300, 650 and $700 \mathrm{~nm}$ (+ diode array detection in the range 200-800 $\mathrm{nm}$ ). System G: system $\mathrm{C}$ with the following gradient $\left[30 \% \mathrm{CH}_{3} \mathrm{CN}\right.$ (5 min), followed by a linear gradient from $30 \%$ to $50 \%$ (10 $\mathrm{min}$ ) and $50 \%$ to $100 \%$ (65 min) of $\mathrm{CH}_{3} \mathrm{CN}$. Dual UV detection was achieved at 220 and $240 \mathrm{~nm}$. System $\mathrm{H}$ : system E with the following gradient $\left[10 \% \mathrm{CH}_{3} \mathrm{CN}\right.$ ( $5 \mathrm{~min}$ ), followed by a linear gradient from $10 \%$ to $30 \%$ (10 $\mathrm{min}), 30 \%$ to $50 \%$ (10 $\mathrm{min}$ ) and $50 \%$ to $100 \%$ (65 min) of $\mathrm{CH}_{3} \mathrm{CN}$ ]. Dual UV detection was achieved at 220 and $240 \mathrm{~nm}$. System I: system A with the following gradient $\left[5 \% \mathrm{CH}_{3} \mathrm{CN}(0.1 \mathrm{~min})\right.$ followed by a linear gradient from $5 \%$ to $100 \%$ ( $5 \mathrm{~min}$ ) of $\mathrm{CH}_{3} \mathrm{CN}$, then $100 \% \mathrm{CH}_{3} \mathrm{CN}$ (3 min)] and dual UV (220 et 260 $\mathrm{nm}$ ) or fluorescence detection, achieved at $45^{\circ} \mathrm{C}$ at the following Ex/Em channels: $634 / 673 \mathrm{~nm}$ and 643/687 nm (sensitivity: 1, PMT auto, filter wheel auto).

\subsection{Synthesis of sulfone-pyronin}

\subsubsection{Sulfone analog of 3,6-diamino-9H-xanthene (3)}


4,4'-Diaminodiphenylmethane ( $4 \mathrm{~g}, 20 \mathrm{mmol}, 1$ equiv) was added into fuming $\mathrm{H}_{2} \mathrm{SO}_{4}-\mathrm{SO}_{3}$ $(96 \%, 20 \mathrm{~mL})$. The resulting mixture was stirred at $80^{\circ} \mathrm{C}$ overnight. The reaction was checked for completion by TLC $\left(\mathrm{CH}_{2} \mathrm{Cl}_{2} / \mathrm{MeOH} 9: 1, \mathrm{v} / \mathrm{v}\right)$ and aq. $5.0 \mathrm{M}$ solution of $\mathrm{NaOH}$ was added until a $\mathrm{pH}$ of 9 was reached. The resulting mixture was extracted with EtOAc $(4 \times 100 \mathrm{~mL})$. The combined organic layers were washed with brine, dried over anhydrous $\mathrm{Na}_{2} \mathrm{SO}_{4}$, filtered and finally evaporated to dryness to give compound $\mathbf{3}$ as a white amorphous solid (4.66 g, yield $83 \%) . \mathrm{R}_{\mathrm{f}}\left(\mathrm{CH}_{2} \mathrm{Cl}_{2} / \mathrm{MeOH} 9\right.$ : 1, v/v) = 0.37; IR (ATR): v3432, 3369, $3355\left(\mathrm{NH}_{2}\right), 1637,1607$, 1489 ( $\mathrm{S}=\mathrm{O}$ stretch), 1437, 1422, 1308, 1275, 1175, 1308, 1275, 1174, 1154, 1133 ( $\mathrm{S}=\mathrm{O}$ stretch), 1040, 963, 921, 855, 831, 796, 700, 689, 632; ${ }^{1} \mathrm{H}$ NMR (500 MHz, DMSO- $\left.d_{6}\right): \delta 7.18(\mathrm{~d}, J=$ $8.2 \mathrm{~Hz}, 2 \mathrm{H}), 7.14(\mathrm{~d}, 2 \mathrm{H}, J=2.4 \mathrm{~Hz}), 6.73(\mathrm{dd}, 2 \mathrm{H}, J=8.2 \mathrm{~Hz}, J=2.4 \mathrm{~Hz}), 5.54(\mathrm{~s}, 4 \mathrm{H}, \mathrm{N} \underline{H})$, $3.84(\mathrm{~s}, 2 \mathrm{H}) ;{ }^{13} \mathrm{C}$ NMR $\left(126 \mathrm{MHz}, \mathrm{DMSO}-d_{6}\right): \delta 147.9,137.6,129,5,125.1,117.2,107.0,31.1$; HPLC (system A): $t_{\mathrm{R}}=3.2 \mathrm{~min}$, purity $=97 \%$ (at $240 \mathrm{~nm}$ ); LRMS (ESI, positive mode, LC-MS coupling): $m / z=260.9[\mathrm{M}+\mathrm{H}]^{+}$and $302.3\left[\mathrm{M}+\mathrm{H}+\mathrm{CH}_{3} \mathrm{CN}\right]^{+}$, calcd for $\mathrm{C}_{13} \mathrm{H}_{12} \mathrm{~N}_{2} \mathrm{O}_{2} \mathrm{~S} 260.1$; Elemental anal.: Found C, 59.6; H, 4.7; N, 10.8; S, $12.6 \mathrm{C}_{13} \mathrm{H}_{12} \mathrm{~N}_{2} \mathrm{O}_{2} \mathrm{~S}$ requires $\mathrm{C}, 60.0 ; \mathrm{H}, 4.7$; $\mathrm{N}, 10.8 ; \mathrm{S}, 12.3$.

\subsubsection{Sulfone analog of 3,6-diaminoxanthone (4) via $\mathrm{FeCl}_{3}$-mediated oxidation}

Compound 3 (745 mg, $2.9 \mathrm{mmol}, 1$ equiv) was dissolved in aq. $2.0 \mathrm{M} \mathrm{HCl}(20 \mathrm{~mL})$. Then, a solution of $\mathrm{FeCl}_{3}(1.4 \mathrm{~g}, 8.6 \mathrm{mmol}, 3$ equiv) in $20 \mathrm{~mL}$ of aq. $2.0 \mathrm{M} \mathrm{HCl}$ was added. The resulting reaction mixture was stirred at $90{ }^{\circ} \mathrm{C}$ overnight. The reaction was monitored by RPHPLC (system A). Despite an incomplete conversion of the starting material (SM), the mixture was cooled to RT and quenched by addition of an aq. $20 \% \mathrm{NaOH}$ solution until a $\mathrm{pH}$ of 8 was reached. The resulting aq. phase was extracted with EtOAc $(4 \times 50 \mathrm{~mL})$. The combined organic layers were dried over anhydrous $\mathrm{Na}_{2} \mathrm{SO}_{4}$, filtered and finally evaporated to dryness. The resulting residue was purified by flash-column chromatography on a silica gel (Sigma-Aldrich 40-63 $\mu \mathrm{m}$; mixture pentane/EtOAc $1: 1, \mathrm{v} / \mathrm{v}$ as eluent) to give two distinct batches containing both the starting compound and the desired ketone with the following ratio determined by RPHPLC (system A) (batch 1: $239 \mathrm{mg}$, ketone/SM $47: 52$ and batch 2: $307 \mathrm{mg}$, ketone/SM 76 : 24, see ESI, Fig. S6). Despite several attempts, it was not possible to obtain a pure sample of ketone 4 in significant amount and these pre-purified mixtures were used in the next step without further purification. Conversely, $\mathrm{Na}_{2} \mathrm{~S}_{2} \mathrm{O}_{8}$-mediated oxidation led to a crude product easier to purify due to complete conversion of SM, but isolated with a dramatically lower yield (4\%). 
Compound 3 (200 mg, $0.8 \mathrm{mmol}, 1$ equiv) and $\mathrm{Na}_{2} \mathrm{~S}_{2} \mathrm{O}_{8}(380 \mathrm{mg}, 1.6 \mathrm{mmol}, 2$ equiv) was dissolved in a mixture $\mathrm{DMF} / \mathrm{H}_{2} \mathrm{O}(2: 1, \mathrm{v} / \mathrm{v}, 12 \mathrm{~mL})$. The resulting reaction mixture was stirred at $80{ }^{\circ} \mathrm{C}$ for $5 \mathrm{~h}$. Monitoring was achieved by RP-HPLC (system A) and revealed no progress. A further amount of $\mathrm{Na}_{2} \mathrm{~S}_{2} \mathrm{O}_{8}$ (1 equiv) was added and the reaction mixture was left under stirring at $80{ }^{\circ} \mathrm{C}$ for a further $4 \mathrm{~h}$. The RP-HPLC monitoring revealed the total conversion of SM into the expected product along with numerous side-products. Solvent were removed and the residue was dissolved in EtOAc $(30 \mathrm{~mL})$ and washed with aq. $5 \% \mathrm{~K}_{2} \mathrm{CO}_{3}$. Organic layer was dried over anhydrous $\mathrm{Na}_{2} \mathrm{SO}_{4}$, filtered and finally evaporated to dryness. The resulting residue was purified by automated flash-column chromatography with a silica gel cartridge ( 25 g, $25 \mu \mathrm{m}$, heptane/EtOAc with a step gradient from $60: 40$ to $30: 70, \mathrm{v} / \mathrm{v}$ as eluent) to give the desired product as a yellow amorphous solid (9 mg, yield 4\%). $\mathrm{R}_{\mathrm{f}}($ EtOAc/heptane $6: 4, \mathrm{v} / \mathrm{v})=$ 0.33; IR (ATR): $v$ 3476, 3443, 3367, 3346, 3227, 2922 (weak, trace of EtOAc), 1725 (weak, trace of EtOAc), 1624, 1581, 1524, 1503, 1483, 1374, 1335, 1309, 1280, 1185, 1130, 1083, 919, 847, 768, 704, 687, 669; ${ }^{1} \mathrm{H}$ NMR (500 MHz, DMSO- $\left.d_{6}\right): \delta 7.92(\mathrm{~d}, J=9.0 \mathrm{~Hz}, 2 \mathrm{H}), 7.12$ $(\mathrm{d}, 2 \mathrm{H}, J=2.5 \mathrm{~Hz}), 6.87(\mathrm{dd}, 2 \mathrm{H}, J=8.5 \mathrm{~Hz}, J=2.5 \mathrm{~Hz}), 6.79(\mathrm{bs}, 4 \mathrm{H}, \mathrm{N} \underline{H}) ;{ }^{13} \mathrm{C}$ NMR $(151$ MHz, DMSO- $\left.d_{6}\right): \delta 174.2,154.0,142.2,130.8,117.5,116.9$, 105.3; LRMS (ESI, positive mode, LC-MS coupling): $m / z=275.2[\mathrm{M}+\mathrm{H}]^{+}$, calcd for $\mathrm{C}_{13} \mathrm{H}_{10} \mathrm{~N}_{2} \mathrm{O}_{3} \mathrm{~S} 274.0$; HPLC (system $\mathrm{F}): t_{\mathrm{R}}=3.7 \mathrm{~min}$, purity $=99 \%$ (at $260 \mathrm{~nm}$ ); UV-vis (recorded during the HPLC analysis): $\lambda_{\max }$ $=249 \mathrm{~nm}, 266 \mathrm{~nm}, 311 \mathrm{~nm}$ and $389 \mathrm{~nm}$; Elemental anal.: Found C, 56.5; H, 4.2; N, 8.5; S, 11.0 $\mathrm{C}_{13} \mathrm{H}_{10} \mathrm{~N}_{2} \mathrm{O}_{3} \mathrm{~S}$. 0.17 EtOAc requires C, 56.8; H, 4.0; N, 9.6; S, 11.0.

\subsubsection{Sulfone-pyronin / sulfone-xanthydrol (1 / 5)}

Impure ketone 4 (batch 1, $239 \mathrm{mg}, 0.87 \mathrm{mmol}, 1$ equiv, please note: mole number was calculated by considering ketone as a pure compound) was dissolved in dry THF (25 mL) and the resulting solution was cooled to $4{ }^{\circ} \mathrm{C}$ with an ice-water bath. Then, $\mathrm{NaBH}_{4}(8 \mathrm{mg}, 0.21$ mmol, 0.25 equiv) was added. The reaction mixture was stirred at RT for $1 \mathrm{~h}$. Monitoring was achieved by RP-HPLC (system A) and revealed no progress of this hydride-mediated reduction. A further amount of $\mathrm{NaBH}_{4}$ ( 0.75 equiv) was added and prolonged heathing at $40{ }^{\circ} \mathrm{C}$ for 3 days led to complete consumption of the ketone. The reaction mixture was cooled to $4{ }^{\circ} \mathrm{C}$ with an ice-water bath and quenched by adding aq. $1.0 \mathrm{M} \mathrm{HCl}$. The crude mixture was diluted with aq. TFA $0.1 \%$ and $\mathrm{CH}_{3} \mathrm{CN}$ and purified by semi-preparative RP-HPLC (system C, $t_{\mathrm{R}}=29.8-30.6$ $\min )$. The product-containing fractions were lyophilized to give the TFA salt of sulfonexanthydrol 5 as a yellow amorphous solid $(9 \mathrm{mg}$, yield $<5 \%$ ). This pure sample contains minor 
amount of blue-colored sulfone-pyronin 1. Despite several attempts (in various deuterated solvents: $\mathrm{CD}_{3} \mathrm{CN}-\mathrm{D}_{2} \mathrm{O}, \mathrm{DMSO}-d_{6}$ and $\mathrm{DMSO}-d_{6}+\mathrm{D}_{2} \mathrm{O}-\mathrm{DCl}$ ), it was not possible to obtain good quality and interpretable ${ }^{1} H$ and ${ }^{13} C$ NMR spectra. LRMS (ESI, positive mode, LC-MS coupling): $m / z=259.1\left[\mathrm{M}-\mathrm{H}_{2} \mathrm{O}+\mathrm{H}\right]^{+}$dehydration occured during the ionization process within ESI probe, calcd for $\mathrm{C}_{13} \mathrm{H}_{12} \mathrm{~N}_{2} \mathrm{O}_{3} \mathrm{~S} 276.1$; HPLC (system A): $t_{\mathrm{R}}=2.8 \mathrm{~min}$, purity $=92 \%$ (at $260 \mathrm{~nm}$ ); UV-vis (recorded during the HPLC analysis): $\lambda_{\max }=229 \mathrm{~nm}$ and $304 \mathrm{~nm}$ (weak).

\subsection{Synthesis of sulfone-rosamine}

\subsubsection{Sulfone analog of $N, N, N^{\prime}, N^{\prime}$-tetraallyl-3, 6-diamino-9H-xanthene (6)}

To a suspension of bis-aniline $3\left(3.1 \mathrm{~g}, 11.5 \mathrm{mmol}, 1\right.$ equiv) and anhydrous $\mathrm{K}_{2} \mathrm{CO}_{3}(6.3 \mathrm{~g}$, $46 \mathrm{mmol}, 4$ equiv) in dry $\mathrm{CH}_{3} \mathrm{CN}(100 \mathrm{~mL})$, was added allyl bromide $(7 \mathrm{~g}, 57.5 \mathrm{mmol}, 5$ equiv). The resulting reaction mixture was stirred at $80{ }^{\circ} \mathrm{C}$ overnight. Reaction monitoring was achieved by RP-HPLC (system B), additional equivalents of allyl bromide ( 2 equiv) were added and the mixture was left under stirring at $80^{\circ} \mathrm{C}$ for a further $6 \mathrm{~h}$. After cooling to RT, the mixture was filtered over a dicalite 4158 pad which was rinsed with $\mathrm{CH}_{2} \mathrm{Cl}_{2}(70 \mathrm{~mL})$. The filtrate was evaporated to dryness and the resulting residue was purified by automated flash-column chromatography with a silica gel cartridge $(80 \mathrm{~g}, 25 \mu \mathrm{m}$, heptane/EtOAc with a step gradient from $100: 0$ to $0: 100, \mathrm{v} / \mathrm{v}$ as eluent) to give the desired $N, N, N^{\prime}, N^{\prime}$-tetraallyl derivative 6 (4.1 g, yield $81 \%$ ) as yellow amorphous solid. $\mathrm{R}_{\mathrm{f}}\left(\mathrm{CH}_{2} \mathrm{Cl}_{2} /\right.$ heptane $\left.9: 1, \mathrm{v} / \mathrm{v}\right)=0.47$; IR (ATR): $v$ 3084, 3055, 3005, 2978, 2849, 1642, 1604, 1497, 1438, 1420, 1391, 1362, 1332, 1292, 1281, 1259, 1210, 1179, 1140, 1042, 990, 953, 934, 921, 908, 844, 815, 788, 705, 670, 624, 608, 554; ${ }^{1} \mathrm{H}$ NMR (500 MHz, DMSO-d $\left.d_{6}\right): \delta 7.33(\mathrm{~d}, 2 \mathrm{H}, J=8.6 \mathrm{~Hz}), 7.09(\mathrm{~d}, 2 \mathrm{H}, J=2.7 \mathrm{~Hz}), 6.85(\mathrm{dd}$, $2 \mathrm{H}, J=8.6 \mathrm{~Hz}, J=2.8 \mathrm{~Hz}), 5.85$ (m, 4H, $\mathrm{H}_{2} \mathrm{C}=\mathrm{C} \underline{H}$-allyl), 5.14 (m, 8H, $\underline{H}_{2} \mathrm{C}=\mathrm{CH}$-allyl), 3.99 (d, $8 \mathrm{H}, J=4.6 \mathrm{~Hz}, \underline{\mathrm{C}}_{2}$-allyl), 3.93 (s, 2H); ${ }^{13} \mathrm{C}$ NMR (126 MHz, DMSO- $d_{6}$ ): $\delta 147.4,138.0$, 134.0, 130.0, 125.8, 116.3, 115.9, 105.7, 52.94, 31.2; LRMS (ESI, positive mode, LC-MS coupling): $m / z=421.0[\mathrm{M}+\mathrm{H}]^{+}$, calcd for $\mathrm{C}_{25} \mathrm{H}_{28} \mathrm{~N}_{2} \mathrm{O}_{2} \mathrm{~S} 420.2$; HPLC (system A): $t_{\mathrm{R}}=6.0 \mathrm{~min}$, purity $=98 \%$ (at $260 \mathrm{~nm}$ ); UV-vis (recorded during the HPLC analysis): $\lambda_{\max }=232 \mathrm{~nm}, 271$ $\mathrm{nm}$ and $337 \mathrm{~nm}$ (weak).

\subsubsection{Sulfone analog of $N, N, N^{\prime}, N^{\prime}$-tetraallyl-3, 6-diaminoxanthone (7)}

p-Chloranil (6.6 g, $26.8 \mathrm{mmol}, 3$ equiv) was added into a solution of compound 6 (3.7 g, 8.9 mmol, 1 equiv) in $\mathrm{C}_{2} \mathrm{H}_{4} \mathrm{Cl}_{2}(100 \mathrm{~mL})$ and the resulting reaction mixture was heated at reflux 
overnight. The reaction was monitored by RP-HPLC (system B), found to be not complete but accompanied by the formation of side-products. Thus, the reaction was quenched by adding aq. $20 \% \mathrm{Na}_{2} \mathrm{SO}_{3}(80 \mathrm{~mL})$ and stirring for $30 \mathrm{~min}$. Thereafter, the aq. phase was extracted with $\mathrm{CH}_{2} \mathrm{Cl}_{2}(3 \times 100 \mathrm{~mL})$ and the combined organic layers were dried over anhydrous $\mathrm{Na}_{2} \mathrm{SO}_{4}$, filtered and finally evaporated to dryness. The resulting residue was subjected to a first column chromatography on a silica gel (Sigma-Aldrich 63-200 $\mu$ m; pentane- $\mathrm{CH}_{2} \mathrm{Cl}_{2} 8: 2$, v/v as eluent) to give a mixture containing the desired ketone as the major product. A second column chromatography purification over smaller particle size silica gel (Merck Geduran ${ }^{\circledR}$ Si 60 40-63 $\mu \mathrm{m}$; pentane- $\mathrm{CH}_{2} \mathrm{Cl}_{2}$ with a step gradient from $5: 5$ to $1: 9$, v/v as eluent) provided the targeted ketone 7 in a pure form $(970 \mathrm{mg}$, yield $25 \%)$ as a green amorphous solid. $\mathrm{R}_{\mathrm{f}}\left(\mathrm{CH}_{2} \mathrm{Cl}_{2}\right.$-pentane $6: 4, \mathrm{v} / \mathrm{v})=0.23$; IR (ATR): $v 3085,2983,2916,1633,1581(\mathrm{C}=\mathrm{O}$ stretch $), 1535,1513,1441$, $1395,1360,1330,1313,1296,1251,1226,1200,1178,1135,1043,993,946,921,901,767$, 703, 669, 622; ${ }^{1} \mathrm{H}$ NMR (500 MHz, DMSO- $\left.d_{6}\right): \delta 8.01$ (d, 2H, $\left.J=8.8 \mathrm{~Hz}\right), 7.06(\mathrm{~m}, 4 \mathrm{H}), 5.89$ (m, 4H, $\mathrm{H}_{2} \mathrm{C}=\mathrm{C} \underline{H}$-allyl), 5.17 (m, 8H, $\underline{H}_{2} \mathrm{C}=\mathrm{CH}$-allyl), $4.14\left(\mathrm{~d}, 8 \mathrm{H}, J=4.3 \mathrm{~Hz}, \underline{\mathrm{C}}_{2}\right.$-allyl); ${ }^{13} \mathrm{C}$ NMR (126 MHz, DMSO- $\left.d_{6}\right): \delta 174.9,152.2,142.5,133.0,130.9,118.4,117.0,116.0,104.4$, 53.1; LRMS (ESI, positive mode, LC-MS coupling): $m / z=435.2[\mathrm{M}+\mathrm{H}]^{+}$, calcd for $\mathrm{C}_{25} \mathrm{H}_{26} \mathrm{~N}_{2} \mathrm{O}_{3} \mathrm{~S}$ 434.2; HPLC (system B): $t_{\mathrm{R}}=3.5 \mathrm{~min}$, purity $=97 \%$ (at $300 \mathrm{~nm}$ ); UV-vis (recorded during the HPLC analysis): $\lambda_{\max }=428 \mathrm{~nm}$; Elemental anal.: Found C, 68.8; H, 6.5; $\mathrm{N}, \quad 6.2 ; \quad \mathrm{S}, \quad 6.3 \quad \mathrm{C}_{26} \mathrm{H}_{26} \mathrm{~N}_{2} \mathrm{O}_{3} \mathrm{~S}$ requires $\mathrm{C}, \quad 69.1 ; \quad \mathrm{H}, \quad 6.0 ; \mathrm{N}, \quad 6.5 ; \quad \mathrm{S}, \quad 7.4$.

\subsubsection{Sulfone analog of $N, N, N^{\prime}, N^{\prime}$-tetraallyl-6-amino-9-(o-tolyl)-3H-xanthen-3-imine (8)}

To a flame-dried flask flushed with argon were added freshly distilled 2-bromotoluene (240 $\mu \mathrm{L}, 2 \mathrm{mmol}, 1$ equiv) and dry THF $(5 \mathrm{~mL})$. The solution was cooled to $-78^{\circ} \mathrm{C}$, and $2.3 \mathrm{M} \mathrm{BuLi}$ solution in hexanes ( $870 \mu \mathrm{L}, 2 \mathrm{mmol}, 1$ equiv) was added dropwise over $5 \mathrm{~min}$. The resulting reaction mixture was stirred at $-78{ }^{\circ} \mathrm{C}$ for $1 \mathrm{~h}$. The halogen-lithium exchange reaction was checked for completion by ${ }^{1} \mathrm{H}$ NMR (quenching of ArLi formed with $\mathrm{MeOH}$ ). A solution of ketone 7 (255 mg, $0.58 \mathrm{mmol}, 0.3$ equiv) in dry THF $(10 \mathrm{~mL})$ was added dropwise (over 10 min) to the crude ArLi solution at $-78{ }^{\circ} \mathrm{C}$ and after that, the mixture was warmed to RT. The reaction was checked for completion by TLC. Thereafter, the mixture was cooled to $4^{\circ} \mathrm{C}$ with an ice-water bath, aq. saturated $\mathrm{NH}_{4} \mathrm{Cl}(10 \mathrm{~mL})$ was added slowly and stirred at $\mathrm{RT}$ for $10 \mathrm{~min}$. The mixture was extracted with $\mathrm{CH}_{2} \mathrm{Cl}_{2}(3 \times 50 \mathrm{~mL})$ and the combined organic layers were dried over anhydrous $\mathrm{Na}_{2} \mathrm{SO}_{4}$, filtered and finally evaporated to dryness. The resulting residue was dissolved in $\mathrm{CH}_{2} \mathrm{Cl}_{2}$-TFA $(9: 1, \mathrm{v} / \mathrm{v}, 10 \mathrm{~mL})$ and the reaction mixture was stirred at $\mathrm{RT}$ for 
30 min (a bright green color typical of $N, N, N^{\prime}, N^{\prime}$-tetraalkyl-sulfone-rosamines immediately appeared).The dehydration reaction was checked for completion by RP-HPLC (system B). Finally, volatiles were evaporated to dryness to give the crude sulfone-rosamine $\mathbf{8}$, which was used in the next step without further purification. LRMS (ESI, positive mode, LC-MS coupling): $m / z=509.2[\mathrm{M}]^{+\circ}$, calcd for $\mathrm{C}_{32} \mathrm{H}_{33} \mathrm{~N}_{2} \mathrm{O}_{2} \mathrm{~S}^{+}$509.2; HPLC (system B): $t_{\mathrm{R}}=5.6$ min; UV-vis (recorded during the HPLC analysis): $\lambda_{\max }=701 \mathrm{~nm}$. During the course of this acidmediated dehydration reaction, partial deprotection of anilines was observed. Sulfonerosamines bearing only two or three $N$-allyl substituents were identified in batch of crude 8 . Triallyl derivative: LRMS (ESI, positive mode, LC-MS coupling): $m / z=469.2[\mathrm{M}]^{+0}$, calcd for $\mathrm{C}_{29} \mathrm{H}_{29} \mathrm{~N}_{2} \mathrm{O}_{2} \mathrm{~S}^{+}$469.2; HPLC (system B): $t_{\mathrm{R}}=5.3$ min; UV-vis (recorded during the HPLC analysis): $\lambda_{\max }=685 \mathrm{~nm}$. Diallyl derivative: LRMS (ESI, positive mode, LC-MS coupling): $m / z=429.2[\mathrm{M}]^{+^{\circ}}$, calcd for $\mathrm{C}_{26} \mathrm{H}_{25} \mathrm{~N}_{2} \mathrm{O}_{2} \mathrm{~S}^{+}$429.2; HPLC (system B): $t_{\mathrm{R}}=4.9$ min; UV-vis (recorded during the HPLC analysis): $\lambda_{\max }=672 \mathrm{~nm}$.

\subsubsection{Sulfone analog of 6-amino-9-(o-tolyl)-3H-xanthen-3-imine (2)}

Crude $N$-tetrallyl derivative 8 (301 mg) and 1,3-dimethylbarbituric acid (413 mg, $2.6 \mathrm{mmol}$, 4.4 equiv, based on $0.58 \mathrm{mmol}$ of 8 theoretically obtained with a quantitative yield for the previous step) were dissolved in degassed $\mathrm{C}_{2} \mathrm{H}_{4} \mathrm{Cl}_{2}(7 \mathrm{~mL})$. Catalytic amount of $\mathrm{Pd}\left(\mathrm{PPh}_{3}\right)_{4}$ (76 mg, $65.7 \mu \mathrm{mol}, 0.11$ equiv) was added and the resulting reaction mixture was stirred at RT for $5 \mathrm{~h}$. The reaction was checked for completion by RP-HPLC (system B). Thereafter, the crude mixture was evaporated to dryness without heating over $35^{\circ} \mathrm{C}$ and the resulting residue was diluted with aq. TFA $0.1 \%$ and $\mathrm{CH}_{3} \mathrm{CN}$ and purified by semi-preparative RP-HPLC (system D). A first pure sample of sulfone-rosamine $2\left(t_{\mathrm{R}}=36.1-39.1 \mathrm{~min}\right)$ was recovered as a TFA salt after freeze-drying (dark blue amorphous powder, $12.2 \mathrm{mg}$ ). The second batch of lower purity was subjected to a second RP-HPLC purification (system E, $t_{\mathrm{R}}=35.1-43.3 \mathrm{~min}$ ). The product-containing fractions were lyophilized to give further $33 \mathrm{mg}$ of 2 (overall yield $20 \%$, based on mass percentage of TFA $=13.1 \%$ determined by ion chromatography, see ESI). IR (ATR): $v$ 3316, 3064, 1671, 1581, 1527, 1377, 1335, 1312, 1225, 1198, 1145, 1048, 904, $834,799,757,720,689,663,569,445,431$; Correct quality and interpretable ${ }^{1} H$ and ${ }^{13} C N M R$ spectra were obtained only after addition of $\mathrm{D}_{2} \mathrm{O}$ in $\mathrm{DMSO}-d_{6}$ (without heavy water, broad and poorly resolved peaks for aromatic protons/carbons were observed, reflecting the cationic resonance hybrid structure of 2). Consequently, signals assigned to hydrated form (deuterated 
triaryl carbinol derivative 9) were mainly observed. ${ }^{1} \mathrm{H} \mathrm{NMR}\left(600 \mathrm{MHz}\right.$, DMSO- $\left.d_{6}+5 \% \mathrm{D}_{2} \mathrm{O}\right)$ : $\delta 8.11(\mathrm{~d}, 1 \mathrm{H}, J=8.4 \mathrm{~Hz}), 7.34$ (pt, 1H, $J=7.5 \mathrm{~Hz}), 7.21$ (pt, 1H, $J=7.5 \mathrm{~Hz}), 7.11(\mathrm{~d}, 2 \mathrm{H}, J=$ $2.4 \mathrm{~Hz}), 6.99$ (d, 1H, $J=7.2 \mathrm{~Hz}), 6.63(\mathrm{dd}, 2 \mathrm{H}, J=8.7 \mathrm{~Hz}, J=2.4 \mathrm{~Hz}), 6.55(\mathrm{~d}, 2 \mathrm{H}, J=9.0$ $\mathrm{Hz}), 1.37$ (s, $3 \mathrm{H}, \mathrm{C}_{3}$-tolyl); ${ }^{13} \mathrm{C}$ NMR (151 MHz, DMSO- $\left.d_{6}+5 \% \mathrm{D}_{2} \mathrm{O}\right): \delta 148.5(2 \mathrm{C}), 145.2$, 136.7 (2C), 134.7, 131.6, 130.3 (2C), 128.6 (2C), 127.5, 126.4, 125.4, 118.2 (2C), 105.3 (2C), 70.8, 20.1; ${ }^{19} \mathrm{~F}$ NMR (282 MHz, DMSO- $\left.d_{6}\right): \delta=-73.8$ (s, 3F, C $\underline{F}_{3}$-TFA); LRMS (ESI, positive mode, LC-MS coupling): $m / z=349.0[\mathrm{M}+\mathrm{H}]^{+}$, calcd for $\mathrm{C}_{20} \mathrm{H}_{16} \mathrm{~N}_{2} \mathrm{O}_{2} \mathrm{~S} 348.1$; HPLC (system $\mathrm{F}): t_{\mathrm{R}}=3.7 \mathrm{~min}$, purity $=95 \%($ at $300 \mathrm{~nm})$, purity $=100 \%($ at $650 \mathrm{~nm})$.

\subsection{PGA-sensitive probe (10)}

Sulfone-rosamine 2 (27 mg, $0.08 \mathrm{mmol}, 1$ equiv) and DIEA (69 $\mu \mathrm{L}, 0.40 \mathrm{mmol}, 5$ equiv) were dissolved in dry $\mathrm{CH}_{3} \mathrm{CN}(5 \mathrm{~mL})$ and cooled to $4{ }^{\circ} \mathrm{C}$. $\mathrm{PhAcCl}(21 \mu \mathrm{L}, 0.16 \mathrm{mmol}, 2$ equiv) was added dropwise and the resulting mixture was stirred at RT for $1 \mathrm{~h}$. Reaction monitoring was achieved by RP-HPLC (system F), additional equivalents of $\mathrm{PhAcCl}$ ( 2 equiv) were added at $4{ }^{\circ} \mathrm{C}$ and the mixture left under stirring at RT for a further $30 \mathrm{~min}$. $\mathrm{MeOH}(10 \mu \mathrm{L})$ was added to quench the excess of acyl chloride and volatiles were evaporated to dryness. The resulting residue was dissolved with aq. TFA $0.1 \%$ and $\mathrm{CH}_{3} \mathrm{CN}$ and purified by semi-preparative RPHPLC (system G). This first purification has led to recovery of a batch of impure probe $\mathbf{1 0}\left(t_{\mathrm{R}}\right.$ $=29.7-32.1 \mathrm{~min}$ ) which was subjected to a second RP-HPLC purification (system $\mathrm{H}, t_{\mathrm{R}}=32.2$ $32.7 \mathrm{~min})$. The product-containing fractions were lyophilized to give less than $1 \mathrm{mg}$ of $\mathbf{1 0}$, as a white amorphous powder. ${ }^{1} \mathrm{H} \mathrm{NMR}\left(500 \mathrm{MHz}, \mathrm{CDCl}_{3}\right): \delta 8.22(\mathrm{dd}, 1 \mathrm{H}, J=1.2 \mathrm{~Hz}, J=7.8 \mathrm{~Hz})$, $7.89(\mathrm{~d}, 2 \mathrm{H}, J=2.3 \mathrm{~Hz}), 7.78(\mathrm{dd}, 2 \mathrm{H}, J=2.3 \mathrm{~Hz}, J=8.7 \mathrm{~Hz}), 7.45-7.30$ (m, 12H), $7.08(\mathrm{~d}, 1 \mathrm{H}$, $J=7.5 \mathrm{~Hz}), 6.92(\mathrm{~d}, 2 \mathrm{H}, J=8.7 \mathrm{~Hz}), 3.76\left(\mathrm{~s}, 4 \mathrm{H}, \mathrm{C} \underline{H}_{2}-\mathrm{PhAc}\right), 1.27$ (s, 3H, C $\underline{H}_{3}$-tolyl); ${ }^{13} \mathrm{C}$ $\mathrm{NMR}\left(126 \mathrm{MHz}, \mathrm{CDCl}_{3}\right)$ : quantity isolated was too small for vizualization of all carbon peaks, despite of extended acquisition time on a $500 \mathrm{MHz}$ spectrometer equipped with a BBI probe (four times more sensitive in carbon than a standard $300 \mathrm{MHz}$ spectrometer); LRMS (ESI, positive mode, LC-MS coupling, cone voltage $75 \mathrm{~V}): m / z=585.3[\mathrm{M}]^{+^{\circ}}$, elimination of chlorine atom occurred during the ionization process within ESI probe, calcd for $\mathrm{C}_{36} \mathrm{H}_{29} \mathrm{~N}_{2} \mathrm{O}_{4} \mathrm{~S}^{+} 585.2$ (for major isotope); LRMS (ESI, positive mode, direct introduction, cone voltage $30 \mathrm{~V}$ ): $\mathrm{m} / \mathrm{z}=$ 620.3 (100), 621.3 (25) and $622.3(10)[\mathrm{M}]^{+^{\circ}}$, calcd for $\mathrm{C}_{36} \mathrm{H}_{29} \mathrm{ClN}_{2} \mathrm{O}_{4} \mathrm{~S} 620.2$ (for major isotope), due to the lack of easily protonable sites within this molecule, only the radical cation as molecular ion was observed. Too avoid chlorine elimination during the ionization process, cone voltage was reduced $(30 \mathrm{~V} v \mathrm{~s} .75 \mathrm{~V})$; $\mathrm{HPLC}$ (system I): $t_{\mathrm{R}}=6.1 \mathrm{~min}$, purity $=91 \%($ at 260 
$\mathrm{nm}$ ); UV (recorded during the HPLC analysis): $\lambda_{\max }=228 \mathrm{~nm}(+$ shoulder at $270 \mathrm{~nm}$ ); UV (PBS, pH 7.4): $\lambda_{\max }=249 \mathrm{~nm}\left(\varepsilon 16410 \mathrm{M}^{-1} \mathrm{~cm}^{-1}\right)$ and $275 \mathrm{~nm}\left(\varepsilon 15740 \mathrm{M}^{-1} \mathrm{~cm}^{-1}\right)$, broad absorption band between 220-280 nm ( $15910 \mathrm{M}^{-1} \mathrm{~cm}^{-1}$ at $260 \mathrm{~nm}$ ); UV (AcONa, pH 3.5): broad absorption band between $220-280 \mathrm{~nm}\left(\varepsilon 16500 \mathrm{M}^{-1} \mathrm{~cm}^{-1}\right.$ at $\left.260 \mathrm{~nm}\right)$.

\subsection{In vitro activation of fluorogenic "turn-on" probe 10 by PGA - experimental details}

\subsubsection{Stock solution of probe and enzyme}

Stock solution $(1 \mathrm{mg} / \mathrm{mL})$ of PGA-sensitive probe $\mathbf{1 0}$ was prepared in $\mathrm{HPLC}$-grade $\mathrm{CH}_{3} \mathrm{CN}$ (final concentration: $1.6 \mathrm{mM}$ ) and subsequently diluted with phosphate buffer (PB, $100 \mathrm{mM}$, $\mathrm{pH}$ 7.4) or acetate buffer $(100 \mathrm{mM}, \mathrm{pH} 3.5)$ for UV-vis absorption, fluorescence measurements and enzyme kinetics. Commercial PGA (841 U mL), aliquoted (samples of $100 \mu \mathrm{L}$ ) and kept frozen at $-20^{\circ} \mathrm{C}$, directly used without dilution.

\subsubsection{Fluorescence assays}

All assays were performed at $37{ }^{\circ} \mathrm{C}$ (using a temperature control system combined with water circulation and conducted with magnetic stirring). For probe $\mathbf{1 0}$ (final concentration in $3.5 \mathrm{~mL}$ fluorescence quartz cell: $1 \mu \mathrm{M}$ ), the fluorescence emission of the released sulfonerosamine 2 was monitored at $\lambda=685 \mathrm{~nm}($ slit $=5 \mathrm{~nm})(\operatorname{Ex} \lambda=640 \mathrm{~nm}$, slit $=5 \mathrm{~nm})$ over time with measurements recorded every $5 \mathrm{~s}$ (overall duration $3600 \mathrm{~s}$ ). $1 \mathrm{U}$ of PGA $(1.2 \mu \mathrm{L})$ was added after 5 min of incubation of the probe in buffer. For kinetic performed in PB, TFA (25$50 \mu \mathrm{L}$ ) was added after $30 \mathrm{~min}$ of incubation, for far-red fluorescence unveiling. Blank experiments to assess the stability of the probe in aqueous buffers, were achieved in the same way but without adding the enzyme.

\subsubsection{HPLC-fluorescence analyses}

Enzymatic reaction mixtures from fluorescence assays were directly analyzed by RPHPLC-fluorescence (injected volume: $10 \mu \mathrm{L}$, system I). 


\section{Results and discussion}

\subsection{Synthesis and stability of sulfone analog of 6-amino-3H-xanthen-3-imine}

Contrary to rhodamines and rosamines, little work has been devoted to the synthesis of heteroatom analogs of pyronins. The only fluorescent molecules already described in the literature, are derived from the pyronin $\mathrm{Y}$ scaffold (O atom is replaced by $\mathrm{SiMe}_{2}$ or $\mathrm{GeMe}_{2}$ moiety, Scheme 1)[56-60] and thus not usable as "smart" photoactive platforms due to the lack of optically tunable primary/secondary amino group(s). Consequently, the analytical use of these fluorophores was not considered, except Ge-pyronin GeP640 used as a thiol-sensitive "ON-OFF" probe and suitable for reversible and dynamic fluorescence imaging of cellular redox self-regulation (i.e., real-time change in the balance between reactive oxygen species (ROS) stress and glutathione (GSH) antioxidant repair processes)[59]. In order to devise effective synthetic routes toward hetero-pyronins bearing two primary anilines, strategies previously explored for preparing hetero-analogs of $N, N, N^{\prime}, N^{\prime}$-tetraalkylrhodamines/rosamines could be a key source of inspiration even if the temporary protection of amino groups might be required both to enhance the solubility of synthesis intermediates and to prevent undesired side-reactions. However, for the synthesis of sulfone analog of 6-amino$3 H$-xanthen-3-imine (sulfone-pyronin 1), we thought that the first steps of synthetic strategy recently proposed by Liu et al. for preparing sulfone-rosamines[44], could be directly applied to commercial 4,4'-diaminodiphenylmethane (Scheme 1). First, one-pot sulfonylation/cyclization leading to cyclic sulfone $\mathbf{3}$ was achieved with oleum acting as both electrophilic sulfonating agent and solvent, at $80{ }^{\circ} \mathrm{C}$ for $12 \mathrm{~h}$. Acid neutralization with an excess of $\mathrm{NaOH}$ and liquid-liquid extraction were enough to recover $\mathbf{3}$ in a pure form with a good $83 \%$ yield. Next, all attempts to directly obtain sulfone-pyronin 1 through oxidative aromatization of this latter 3,6-diamino-hetero-xanthene derivative failed. Indeed, the use of DDQ in DMF led to a complex mixture of many unidentified products along with a minute proportion of 1. Other oxidants such as $\mathrm{FeCl}_{3}$ in aq. $4.0 \mathrm{M} \mathrm{HCl}\left(\right.$ at $50{ }^{\circ} \mathrm{C}$ ) or $\mathrm{NaIO}_{4}$ in $\mathrm{CH}_{3} \mathrm{CN}$ $\mathrm{H}_{2} \mathrm{O}$ mixture (at $60{ }^{\circ} \mathrm{C}$ ) provided the 9-keto derivative 4. Consequently, we have considered an alternative aromatization procedure involving oxidation of the activated methylene group to ketone, followed by reduction to the corresponding benzhydryl alcohol and final acidmediated dehydration. Thus, 3 was treated with an excess of $\mathrm{FeCl}_{3}$ (3 equiv) in aq. $2.0 \mathrm{M} \mathrm{HCl}$ at $90{ }^{\circ} \mathrm{C}$ for $12 \mathrm{~h}$, to give 3,6-diamino- $9 H$-xanthen-9-one 4. Despite several chromatographic purification attempts, it was not possible to obtain this ketone in a pure form and a mixture of 
3 and 4 was used in the next step. Other oxidants were tested (i.e., activated $\mathrm{MnO}_{2}$ in DMF and at $\mathrm{Na}_{2} \mathrm{~S}_{2} \mathrm{O}_{8}$ in DMF- $\mathrm{H}_{2} \mathrm{O}$ mixture at $80-90{ }^{\circ} \mathrm{C}$ ). Despite a complete conversion of $\mathbf{3}$, an increased number of side-products was observed causing a dramatic drop in the isolated yield of pure 4 (see paragraph 2.4.2). Reduction was achieved using a moderate excess of $\mathrm{NaBH}_{4}$ in dry THF, and the resulting sulfone-xanthydrol 5 was subjected to an acidic treatment to yield the blue-colored sulfone-pyronin 1. Due to its high polarity, this fluorophore was readily purified by semi-preparative RP-HPLC, but despite the use of acidic aq. mobile phase (i.e., aq. TFA $0.1 \%, \mathrm{pH} 1.9$ ), almost complete conversion of 1 into its colorless and non-emissive C9benzhydrol form $\mathbf{5}$ was observed during this liquid chromatographic isolation procedure.

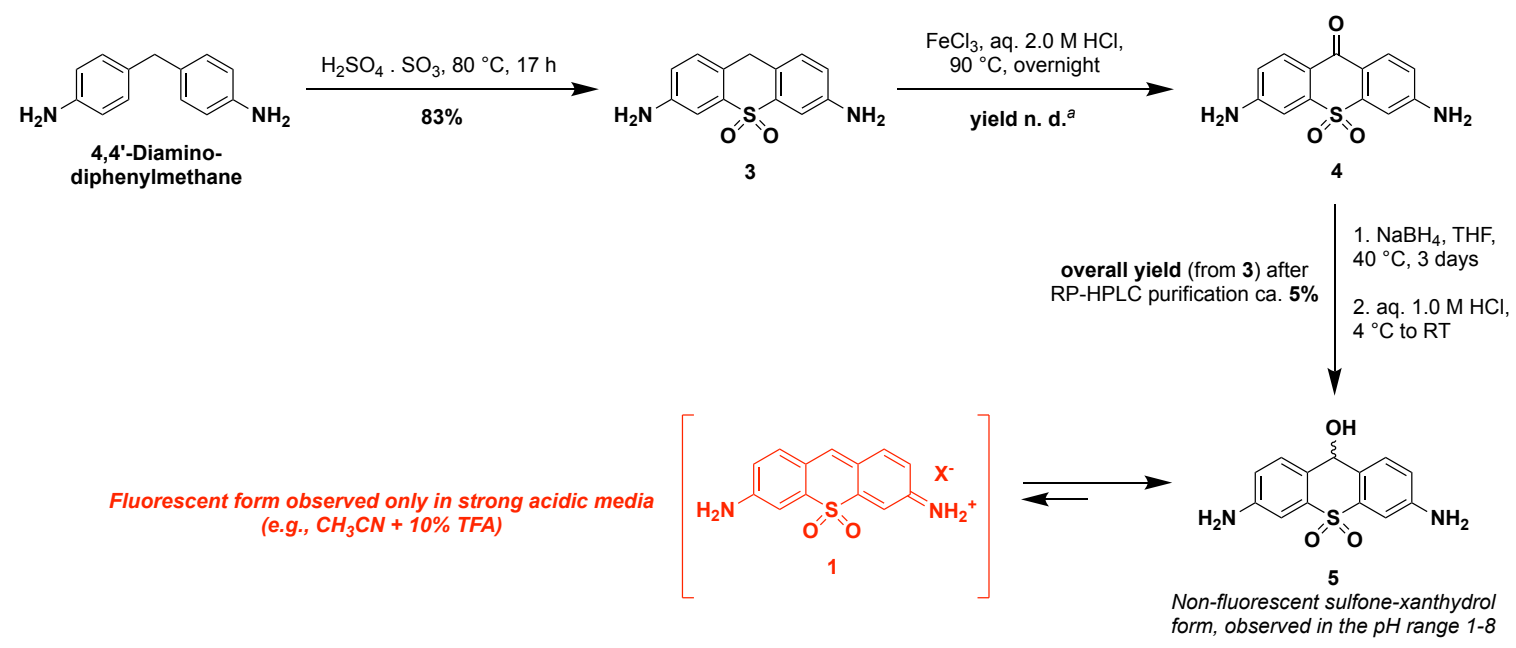

Scheme 1. Synthesis of sulfone-pyronin 1 (in square brackets to reflect that this fluorophore is not stable under standard conditions) in equilibrium with its hydrated form namely sulfone-xanthydrol $\mathbf{5}$ (TFA salt, $\mathrm{X}^{-}=\mathrm{CF}_{3} \mathrm{CO}_{2}^{-}$, $\mathrm{RT}=$ room temperature). ${ }^{a}$ yield not determined because it was impossible to isolate ketone 3 in a pure form.

This surprising result is explained on the basis of nucleophilic attack of a water molecule at the C9 position of $\mathbf{1}$ whose electrophilic character is strengthened by the strong electronwithdrawing ability of the sulfone group. To the best of our knowledge, very few examples of hetero-xanthene dyes with meso-position highly sensitivity towards nucleophilic addition have been already highlighted in the literature[39]. Worth mentioning in this context is Ge-pyronin GeP640 reactive towards biological thiols at physiological $\mathrm{pH}$ (vide supra) and not under acidic conditions[59]. The structure of $\mathbf{5}$ was confirmed by ESI mass spectrometry (see ESI, Fig. S13) but we did not manage to get well-resolved and interpretable NMR spectra whatever the deuterated solvent used $\left(\mathrm{CD}_{3} \mathrm{CN}-\mathrm{D}_{2} \mathrm{O}\right.$, DMSO- $d_{6}$ and DMSO- $\left.d_{6}+\mathrm{D}_{2} \mathrm{O}-\mathrm{DCl}\right)$, probably, due to rapid equilibrium between different forms including $\mathbf{1}$ and $\mathbf{5}$. Its good purity (92\%) was confirmed by RP-HPLC analysis and the mass percentage of TFA $(23.4 \%)$ in sample was determined by ion chromatography. Furthermore, this benzhydryl alcohol exhibits a marked 
electronic absorption in the UV-A range (Abs $\lambda_{\max }=329 \mathrm{~nm}$ with $\varepsilon 6500 \mathrm{M}^{-1} \mathrm{~cm}^{-1}$ in DMSO). To determine the spectral features of the blue-colored and fluorescent form 1, we explored different solvent conditions that may prevent or minimize Michael type addition of water and thus favoring the predominance of this full $\pi$-conjugated molecule. Thus, in $\mathrm{CH}_{3} \mathrm{CN}$ containing $10 \%$ of TFA, we observe a broad and intense absorption band centered at $\lambda=632 \mathrm{~nm}$ ( $\varepsilon 19$ $570 \mathrm{M}^{-1} \mathrm{~cm}^{-1}$ ) assigned to the $0-0$ band of the $\mathrm{S} 0 \rightarrow \mathrm{S} 1$ transition (Fig. 3). A less-pronounced shoulder peak at the higher-energy side is also noticed and is attributed to the vibronic relaxation (the 0-1 vibrational band). Excitation at $580 \mathrm{~nm}$ leads to a significantly Stokesshifted intramolecular charge transfer (ICT) emission band centered at $671 \mathrm{~nm}$ (full-width half maximum, $\Delta \lambda_{1 / 2 \max }=75 \mathrm{~nm}$ ). For fluorophore solutions with concentration below $10 \mu \mathrm{M}$, a linear relationship between absorbance and fluorescence emission was obtained and thus the accurate determination of fluorescence quantum yield was achieved $\left(\Phi_{\mathrm{F}}=14 \%\right.$ determined using sulfoindocyanine dye Cy 5.0 as standard $\left(\Phi_{\mathrm{F}}=20 \%\right.$ in PBS $\left.)[55]\right)$.
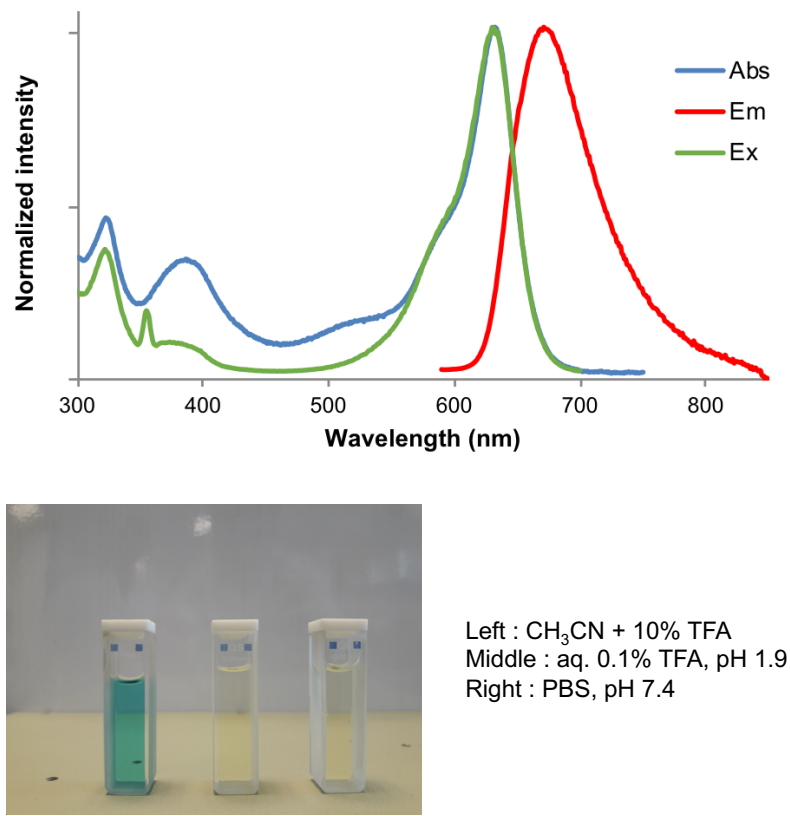

Left : $\mathrm{CH}_{3} \mathrm{CN}+10 \%$ TFA

Middle : aq. $0.1 \%$ TFA, pH 1.9

Right : PBS, $\mathrm{pH} 7.4$

Fig. 3. (Top) Normalized absorption (blue), excitation (Em $710 \mathrm{~nm}$, slit $5 \mathrm{~nm}$, green) and emission (Ex $580 \mathrm{~nm}$, slit $5 \mathrm{~nm}$, red) spectra of sulfone-pyronin 1 in $\mathrm{CH}_{3} \mathrm{CN}+10 \%$ TFA at $25^{\circ} \mathrm{C}$. (Bottom) Picture of solutions (concentration: $18.5 \mu \mathrm{M}$ ) of sulfone-pyronin 1 / sulfone-xanthydrol 5 in $\mathrm{CH}_{3} \mathrm{CN}+10 \%$ TFA, aq. $0.1 \% \mathrm{TFA}(\mathrm{pH}$ $1.9)$ and PBS (pH 7.4) respectively.

However, for higher concentrations, the absorption and excitation spectra were not perfectly superimposable (Fig. 3), suggesting the presence of several absorbing species in solution, and the persistence of equilibrium between forms $\mathbf{1}$ and $\mathbf{5}$ even in strong acidic medium. All these experimental observations clearly confirm the poor stability of sulfone-pyronins in aq. media whatever the $\mathrm{pH}$ value, that precludes their use as fluorescent reporters in bioanalytical 
applications. However, one can speculate that this novel type of NIR fluorophores may be useful for devising novel reaction-based sensing schemes readily applicable to non-aqueous environments or matrices. Indeed, analytes that are able to react with 9-OH of sulfonexanthydrols to convert it into good leaving group (e.g., electrophilic pollutants or chemical warfare agents including phosgene and organophosphorus compounds)[61], will trigger 1,6elimination process leading to aromatization and fluorescence unveiling (Fig. 4)[62]. In order to improve the aq. stability of sulfone-xanthene dyes, we next explored the synthesis of sulfone-rosamines for which C-9 position is sterically hindered through its substitution with an aryl group.
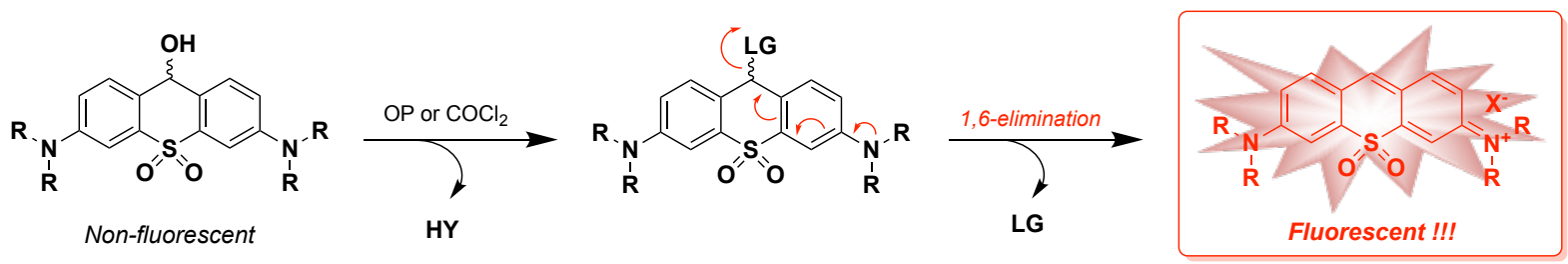

Fig. 4. Proposed reaction-based sensing mechanism for the detection of organophosphorus compounds $(\mathrm{OP}=$ organophosphate or organophosphonate) or phosgene using a sulfone-xanthydrol derivative as fluorogenic probe $\left(\mathrm{R}=\mathrm{Me}\right.$ or Et, $\mathrm{Y}^{-}=\mathrm{Cl}^{-}$or leaving group of $\mathrm{OP}, \mathrm{LG}=$ leaving group $=\mathrm{OC}(\mathrm{O}) \mathrm{Cl}$ in the case of phosgene, $\mathrm{X}^{-}=\mathrm{Cl}^{-}$ in the case of phosgene).

\subsection{Synthesis of sulfone analog of 6-amino-9-(o-tolyl)-3H-xanthen-3-imine}

Among the set of sulfone analogs of $N, N, N^{\prime}, N^{\prime}$-tetramethylrosamines reported by Liu et al., the dye molecule $\mathbf{S O}_{2} \mathbf{R 2}$ bearing $o$-tolyl group as C-9 aryl substituent is easily synthesized through the nucleophilic addition of the corresponding organolithium reagent to the sulfonexanthone (yield 52\%)[44]. Furthermore, this sulfone-rosamine exhibits a quite satisfying stability within the $\mathrm{pH}$ range 2-8 allowing to achieve its complete photophysical characterization in simulated physiological conditions $\left(\mathrm{Abs} / \mathrm{Em} \lambda_{\max }=703 / 742 \mathrm{~nm}, \Phi_{\mathrm{F}}=\right.$ $7.3 \%$ ). In view of these results, we planned the preparation of the fluorogenic version of $\mathbf{S O}_{2} \mathbf{R 2}$ bearing two optically tunable primary amino groups (Scheme 2). As previously mentioned (vide supra) and by analogy with the synthetic route towards phospha-fluorescein, published by Fukazawa et al.[63], the allyl moiety was used as protecting group (both to remove NH "acidic" protons and to enhance solubility of intermediates in organic solvents) that is stable under a variety of conditions (especially in the presence of $\mathrm{ArLi}$ ) and easily removed by $\mathrm{Pd}(0)$-catalysis under mild and neutral conditions. 


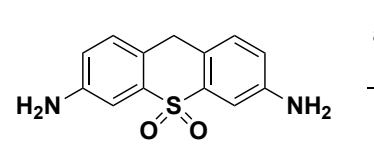

3

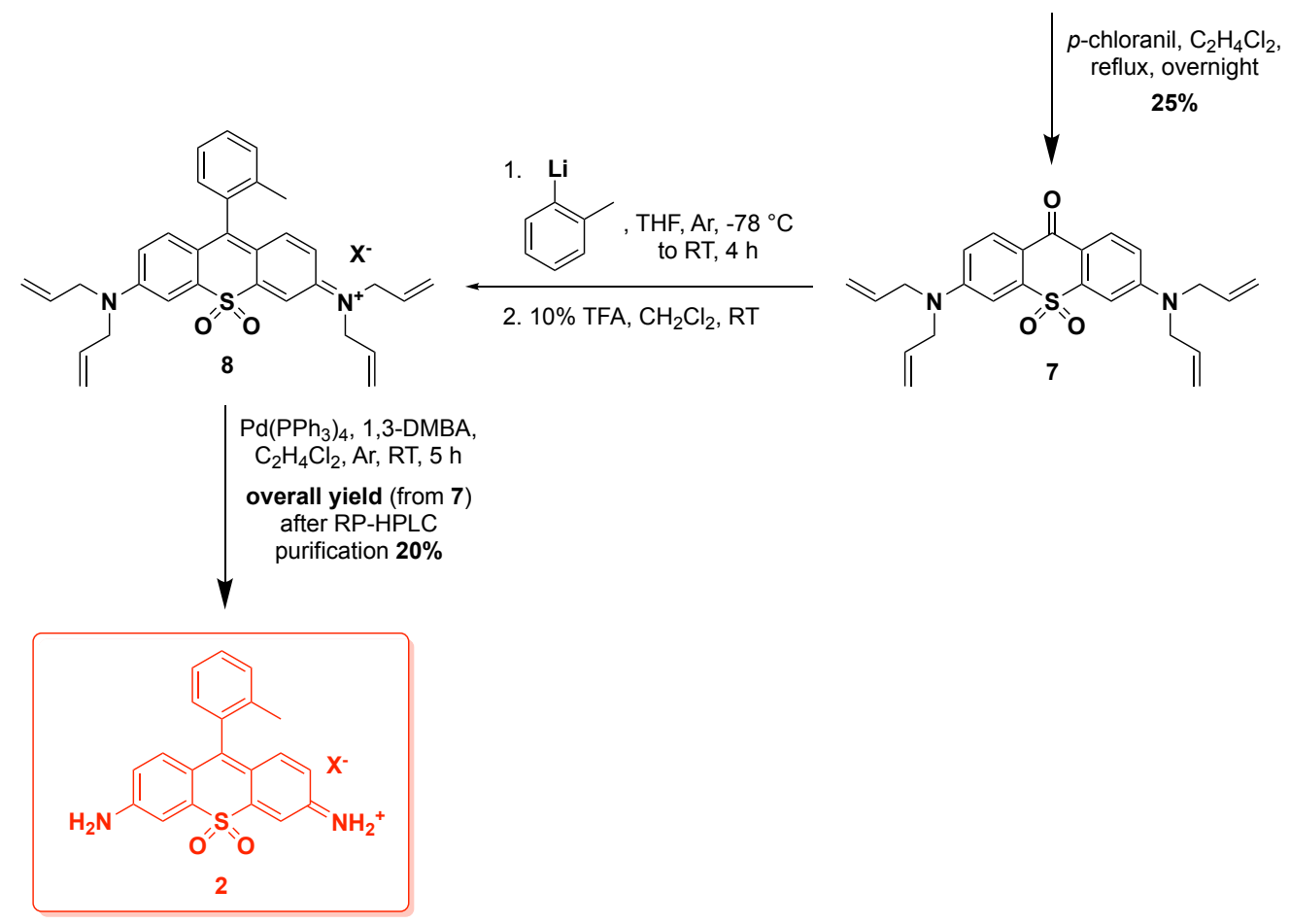

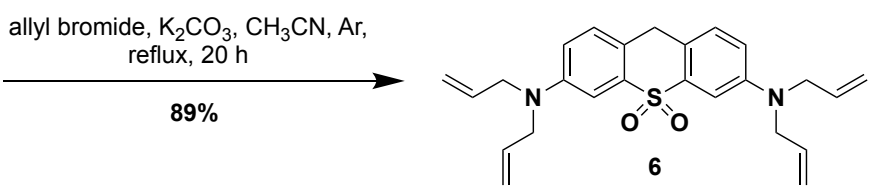

-chloranil, $\mathrm{C}_{2} \mathrm{H}_{4} \mathrm{Cl}_{2}$, , overnight

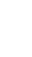


treatment and purification attempts of $\mathbf{8}$, we noted the significant premature cleavage (photoassisted ?) of some allyl protecting groups leading to a mixture of several sulfone-rosamines that could not be separated by conventional silica gel column chromatography. Finally, this crude mixture was subjected to a short treatment with cat. amount of $\mathrm{Pd}\left(\mathrm{PPh}_{3}\right)_{4}$ and large excess of 1,3-dimethylbarbituric acid (4.4 equiv) in degassed $\mathrm{C}_{2} \mathrm{H}_{4} \mathrm{Cl}_{2}$ to achieve complete deprotection of primary anilines and to afford blue-colored sulfone-rosamine 2. Careful monitoring of this reaction through HPLC-MS analyses was found to be essential because a too long reaction time led to complete disappearance of this free aniline-based fluorophore and formation of many numerous unidentified side-products. Purification was achieved by RPHPLC to give 2 as a TFA salt (mass percentage of TFA in freeze-dried sample $=13.1 \%$, determined by ion chromatography) and in a moderate yet not optimized overall yield (20\%) from 7. All spectroscopic data (see ESI for the corresponding spectra, Fig. S24-S30), especially IR, NMR and mass spectrometry, were in agreement with the structure assigned. Its high level of purity was confirmed by RP-HPLC analysis and found to be in the range $95-100 \%$ depending on the wavelength used for UV-visible detection.

\subsection{Stability and photophysical characterization of sulfone analog of 6-amino-9-(o-tolyl)-3H- xanthen-3-imine}

To know if meso-substitution is an effective way to dramatically improve the aqueous stability of sulfone-xanthene scaffold, it was deemed necessary to study the spectral behavior of 9-(o-tolyl) derivative 2 over the $\mathrm{pH}$ range 1.9-7.4. This was achieved by incubating this fluorophore in various buffers (i.e., phosphate, acetate and HPLC acidic mobile phases), and monitoring its absorbance at $645 \mathrm{~nm}$ over time, which is lost upon conversion to nonfluorescent triaryl carbinol 9 (Fig. 5). To our surprise, sulfone-rosamine 2 exhibits a short halflife of ca. $10 \mathrm{~min}$ in buffers whose $\mathrm{pH}>5$ (see Fig. 5 for pseudo first-order rate constants and hydrolysis half-lives and ESI for details about determination of kinetics parameters), which prevents its photophysical characterization under simulated physiological conditions, contrary to what has been achieved by Liu et al. with $N, N, N^{\prime}, N^{\prime}$-tetramethyl sulfone-rosamine $\mathbf{S O}_{2} \mathbf{R 2}[44]$. A possible hypothesis to explain these apparently contradictory results, is that the greater electron-donating ability of dimethylamino groups as compared with amino groups may reduce the electrophilicity of C-9 position in $\mathbf{S O}_{2} \mathbf{R} 2$ and thus the reactivity of this sulfonexanthene dye toward water molecule or hydroxyde anion. In acetate buffers, 2 is shown to 
hydrolyze more slowly $\left(k_{1, \mathrm{obs}}=8.610^{-4} \mathrm{sec}^{-1}\right.$ and $6.310^{-4} \mathrm{sec}^{-1}$ at $\mathrm{pH} 3.8$ and 3.4 respectively) and incomplete conversion to colorless triaryl methanol 9 is achieved $(60 \%$ and $35 \%$ at $\mathrm{pH} 3.8$ and 3.4 respectively), suggesting that the NIR fluorescence of sulfone-rosamine 2 could be unveiled and observed in acidic aqueous buffered environments. This trend is enhanced in aqueous solutions with $\mathrm{pH}$ lower than 2.5. Indeed, in aq. TFA $0.1 \%$ and in aq. formic acid $0.1 \%$, the fluorophore is fully-stable which has made possible its purification by RP-HPLC (vide supra).

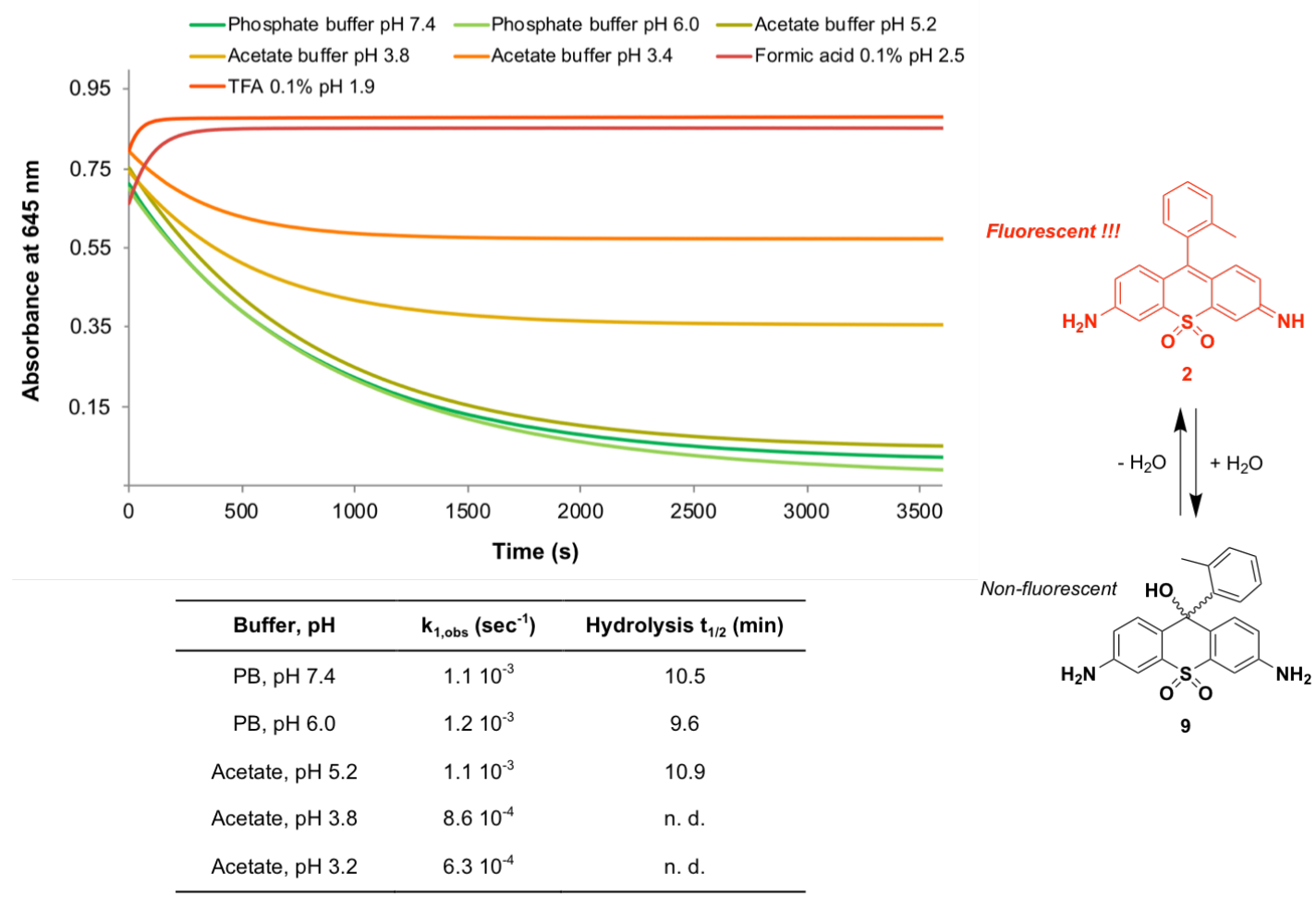

Fig. 5. Aqueous stability of sulfone-rosamine 2 at $25^{\circ} \mathrm{C}$ : (Top left) UV-vis absorbance over time; (Bottom left) determination of pseudo first-order rate constants $\left(k_{1, \mathrm{obs}}\right)$ and hydrolysis half-life $\left(\mathrm{t}_{1 / 2}\right)(\mathrm{n}$. d. $=$ not determined due to incomplete hydrolysis). (Right) Sulfone-rosamine 2 in equilibrium with its hydrated form 9. Please note: the slight increase of absorbance at $645 \mathrm{~nm}$ observed during the incubation of 2 in aq. acidic solutions $(\mathrm{pH}<2.5)$ is explained by the presence of a small amount of hydrated form 9 in DMSO stock solution of 2 which is rapidly converted into blue-colored sulfone-rosamine.

Therefore, we decided to investigate the photophysical properties of $\mathbf{2}$ in aq. formic acid $0.1 \%$ ( $\mathrm{pH} \mathrm{2.5)} \mathrm{(Fig.} \mathrm{6).} \mathrm{The} \mathrm{UV-vis} \mathrm{absorption} \mathrm{spectrum} \mathrm{is} \mathrm{quite} \mathrm{similar} \mathrm{to} \mathrm{that} \mathrm{of} \mathrm{sulfone-}$ pyronin 1 recorded in $\mathrm{CH}_{3} \mathrm{CN}+10 \%$ TFA (vide supra), and displays a maximum at $643 \mathrm{~nm}(\varepsilon$ $17420 \mathrm{M}^{-1} \mathrm{~cm}^{-1}$ ). The fluorescence emission curve shows a peak maximum at $687 \mathrm{~nm}$ (fullwidth half maximum, $\Delta \lambda_{1 / 2 \max }=75 \mathrm{~nm}$ ). By comparison with parent rosamine 2 Me RG $\left(\mathrm{Abs} / \mathrm{Em} \lambda_{\max }=498 / 520 \mathrm{~nm}\right.$ in PBS, $\left.\mathrm{pH} 7.4\right)[64,65]$, the replacement of the xanthene 10position $\mathrm{O}$ atom by a sulfone group leads, on the one hand, to the expected dramatic red-shift 
in the fluorescence maxima, and on the other hand, to unanticipated increase of Stokes shift (44 $\mathrm{nm} / 995 \mathrm{~cm}^{-1}$ compared to $22 \mathrm{~nm} / 850 \mathrm{~cm}^{-1}$ for $\mathbf{2 M e ~ R G ) . ~ T h i s ~ m i g h t ~ b e ~ a t t r i b u t e d ~ t o ~ a n ~}$ excited-state ICT. This latter effect is greatly enhanced in sulfone-rosamine dyes because of the strong electron withdrawing capability of the $\mathrm{SO}_{2}$ moiety[66,30]. Interestingly, a good matching between the absorption and excitation spectra is observed (Fig. 6), supporting the lack of H-type aggregates in acidic aqueous solutions. Thus, it was possible to determine the fluorescence quantum yield $\left(\Phi_{\mathrm{F}}=6 \%\right)$ using sulfoindocyanine dye Cy 5.0 as standard $\left(\Phi_{\mathrm{F}}=\right.$ $20 \%$ in PBS)[55], which is of the same order of magnitude as those reported by Liu et al. for $N, N, N^{\prime}, N^{\prime}$-tetramethyl sulfone-rosamine dyes in PBS at physiological $\mathrm{pH}[44]$.

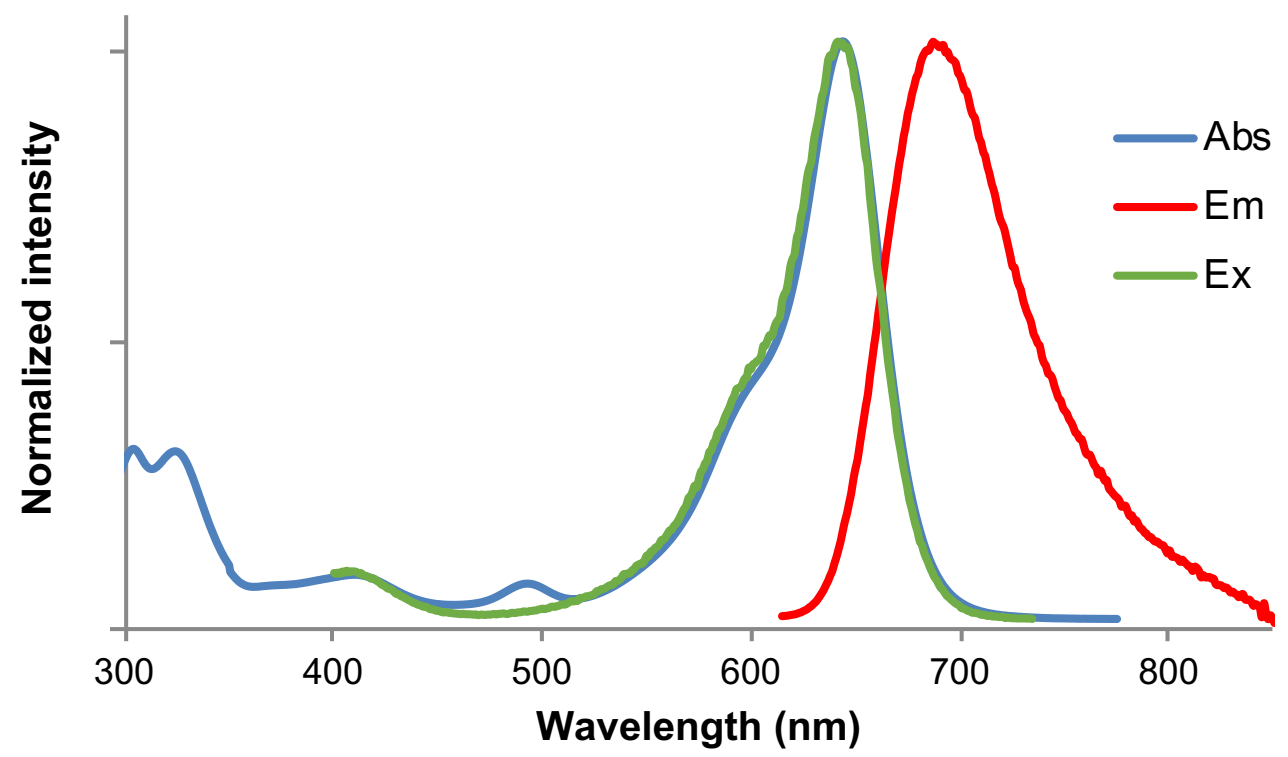

Fig. 6. Normalized absorption (blue), excitation (Em $750 \mathrm{~nm}$, slit $5 \mathrm{~nm}$, green) and emission (Ex $600 \mathrm{~nm}$, slit 5 $\mathrm{nm}$, red) spectra of sulfone-rosamine 2 in aq. $0.1 \%$ formic acid $(\mathrm{pH} 2.5)$ at $25^{\circ} \mathrm{C}$.

In the light of all this, it is obvious that these hetero-xanthene-based fluorophores may find applications in sensing and bioimaging, through their implementation as chemodosimeters or probes in sample matrices or in living biological systems which the $\mathrm{pH}$ level is sufficiently low to unveil their NIR emission[67]. A valuable example might be the development of fluorescent probes that target acidic organelles known to play specific and indispensable roles in cellular processes[68-71]. In this context, the lysosome, a key constituent of cellular digestive system containing hydrolytic enzymes that function only under acidic conditions, could be an attractive target. However, the ability of NIR fluorescent scaffold $\mathbf{2}$ to be readily converted into enzymesensitive "smart" probes still has to be demonstrated. 
3.4 Fluorogenic reactivity of sulfone-rosamine 2. Synthesis and in vitro validations of PGAsensitive probe 10

To demonstrate that the primary amino groups of sulfone-rosamine $\mathbf{2}$ can be used as effective fluorescence switches for enzyme sensing purposes, we planned to synthesize a "turn-on" amidase-responsive fluorescent probe (Scheme 3). Penicillin G acylase (PGA, also known as penicillin amidase) was chosen as model protease because this hydrolytic enzyme has two clear advantages: (1) a structurally simple substrate (phenylacetamide) than can be easily installed on the sulfone-rosamine $\mathbf{2}$ through amidification of its primary anilines and (2) a commercial availability at low cost[72]. The relevance of this choice is supported by the routine use of PGA as biocatalyst for the synthesis of $\beta$-lactam antibiotics, since it allows for the deprotection of phenylacetyl-protected amines[73], or to perform in vitro validations of self-immolative molecular systems used as diagnostic probes, molecular amplifiers or drug delivery systems[74-76]. Bis-amidation of 2 was achieved by treatment with an excess of phenylacetyl chloride ( $\mathrm{PhAcCl}, 4$ equiv) and DIEA (5 equiv) in dry $\mathrm{CH}_{3} \mathrm{CN}$ (Scheme 3).

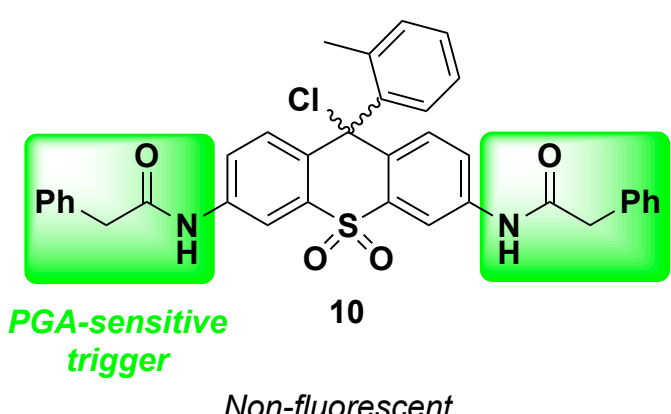

Non-fluorescent

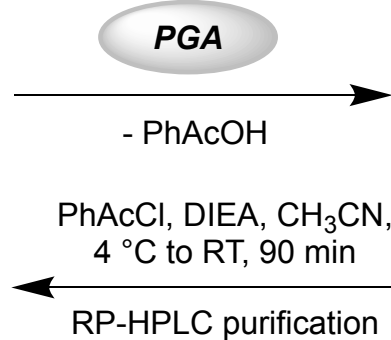

RP-HPLC purification

Scheme 3. Synthesis of PGA-sensitive probe $\mathbf{1 0}$ and its enzymatic activation.

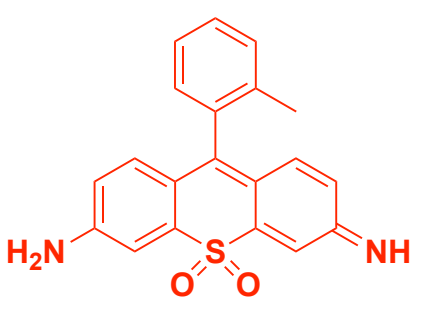

2

Fluorescent !!!

The only difficulty associated with this synthetic procedure was related to the isolation of the PGA-sensitive probe $\mathbf{1 0}$ with a satisfying yield. Indeed, during the reaction monitoring by TLC and HPLC-MS analyses, we observed that the chlorine atom at the C-9 position could be replaced by various nucleophile species (e.g., $\mathrm{MeOH}$, water, formic acid, ...) leading to a mixture of bis-phenylacetamide derivatives of sulfone-rosamine. Two successive purifications by RP-HPLC provided a pure sample of fluorogenic PGA substrate 10. Spectroscopic data, in particular ${ }^{1} \mathrm{H}$ NMR and mass spectrometry, were in agreement with the structure assigned. As expected, 10 proved to be colorless (only UV absorbance in the range $220-280 \mathrm{~nm}$ is observed, see ESI for the corresponding spectra, Fig. S35) and non-fluorescent in both phosphate and 
acetate buffers (pH 7.4 and 3.4 respectively) and its sensing response to PGA was studied by time-dependent fluorescence analysis (Fig. 7).

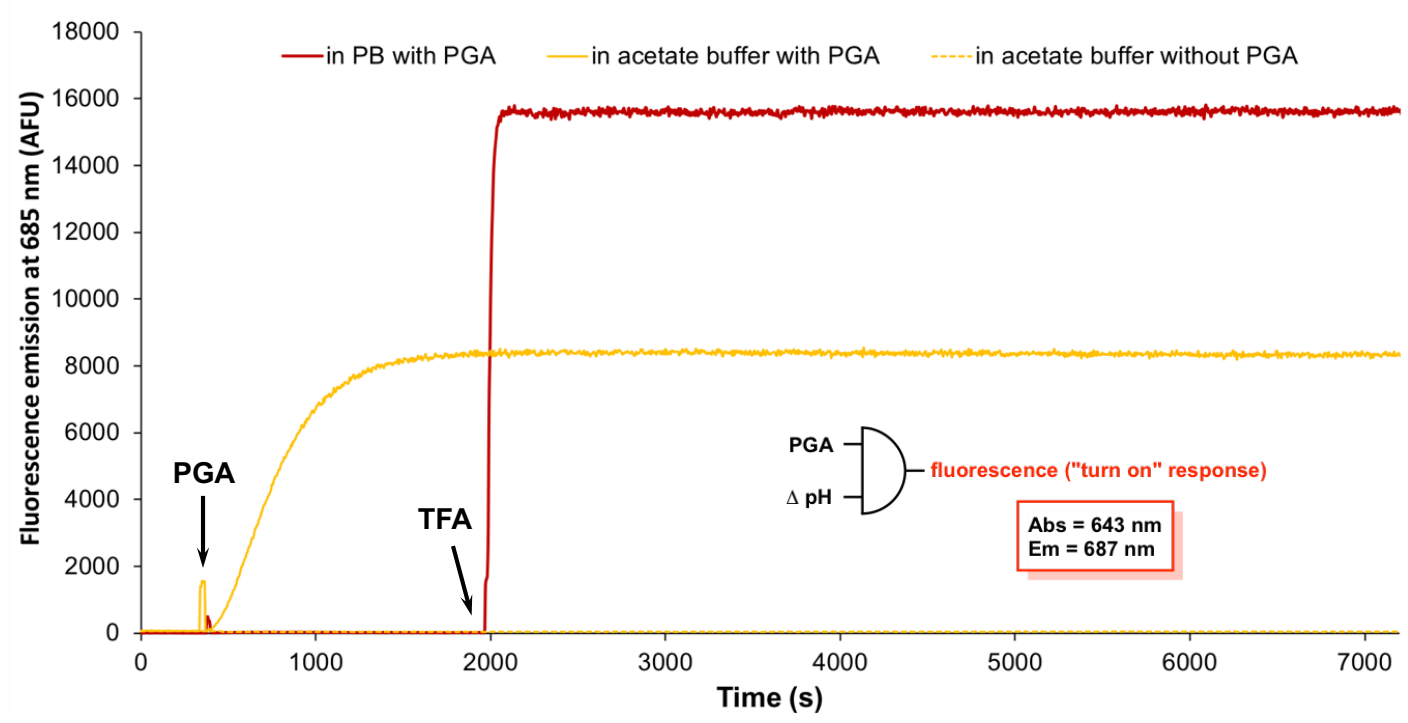

Fig. 7. Time-dependant changes in the far-red fluorescence intensity (Ex/Em 640/685 nm, slit $5 \mathrm{~nm}$ ) of fluorogenic probe 10 (acting as a "AND" fluorescent molecular logic gate, concentration: $1 \mu \mathrm{M}$ ) in the presence of PGA (1 U) at $37^{\circ} \mathrm{C}$. Please note: $P G A$ was added after 5 min of incubation of probe in buffer alone. For enzymatic activation performed in phosphate buffer ( $p H$ 7.4), TFA was added after 33 min of incubation with enzyme for fluorescence unveiling.

First, this fluorescence-based in vitro enzyme assay was performed at physiological $\mathrm{pH}$ (phosphate buffer, $\mathrm{pH} 7.4$ ) and at $37^{\circ} \mathrm{C}$, where both stability and activity of PGA are assumed to be optimal[77]. Since sulfone-rosamine 2, released upon enzymatic cleavage of carboxamide bonds, is not stable under these buffered conditions (vide supra), the strong farred fluorescence signal at $685 \mathrm{~nm}(\mathrm{Ex}$ at $640 \mathrm{~nm})$ assigned to this hetero-xanthene dye, was observed only after adding excess of TFA to dramatically lower the $\mathrm{pH}$ of the assay mixture. To avoid the use of this exogenous reagent for fluorescence unveiling, we next explored enzymatic activation of probe $\mathbf{1 0}$ in acetate buffer ( $\mathrm{pH}$ 3.4). In such cases, a significant and gradual increase of far-red fluorescence of sulfone-rosamine 2 (Ex/Em 640/685 nm) was observed. A plateau indicating the complete hydrolysis of $\mathbf{1 0}$ by PGA, was reached within about $30 \mathrm{~min}$ and a 70-fold increase in fluorescence was finally obtained (460-fold increase in phosphate buffer after addition of TFA, see ESI for the corresponding fluorescence emission spectra, Fig. S35 and S36). Furthermore, no fluorescence signal changes were observed in the absence of amidase, confirming the full stability of the probe in aqueous buffers. Finally, the presence of sulfone-rosamine dye $\mathbf{2}$ in these enzymatic reaction mixtures was unambiguously confirmed by RP-HPLC analyses (fluorescence detection, $t_{\mathrm{R}}=3.8 \mathrm{~min}$ ) and compared with an authentic sample of synthetic sulfone-rosamine 2 used as reference (Fig. 8). All these results 
demonstrate the potential utility of sulfone-rosamine dyes bearing primary aniline(s), as fluorogenic labels in reaction-based probes. Furthermore, PGA-sensitive probe $\mathbf{1 0}$ acts as a two-input "AND" molecular logic gate[78,79] because its cloaked fluorescence reporter signal is "turned-on" by the combined action of two distinct biostimuli: enzyme activity and acidification (Fig. 7).
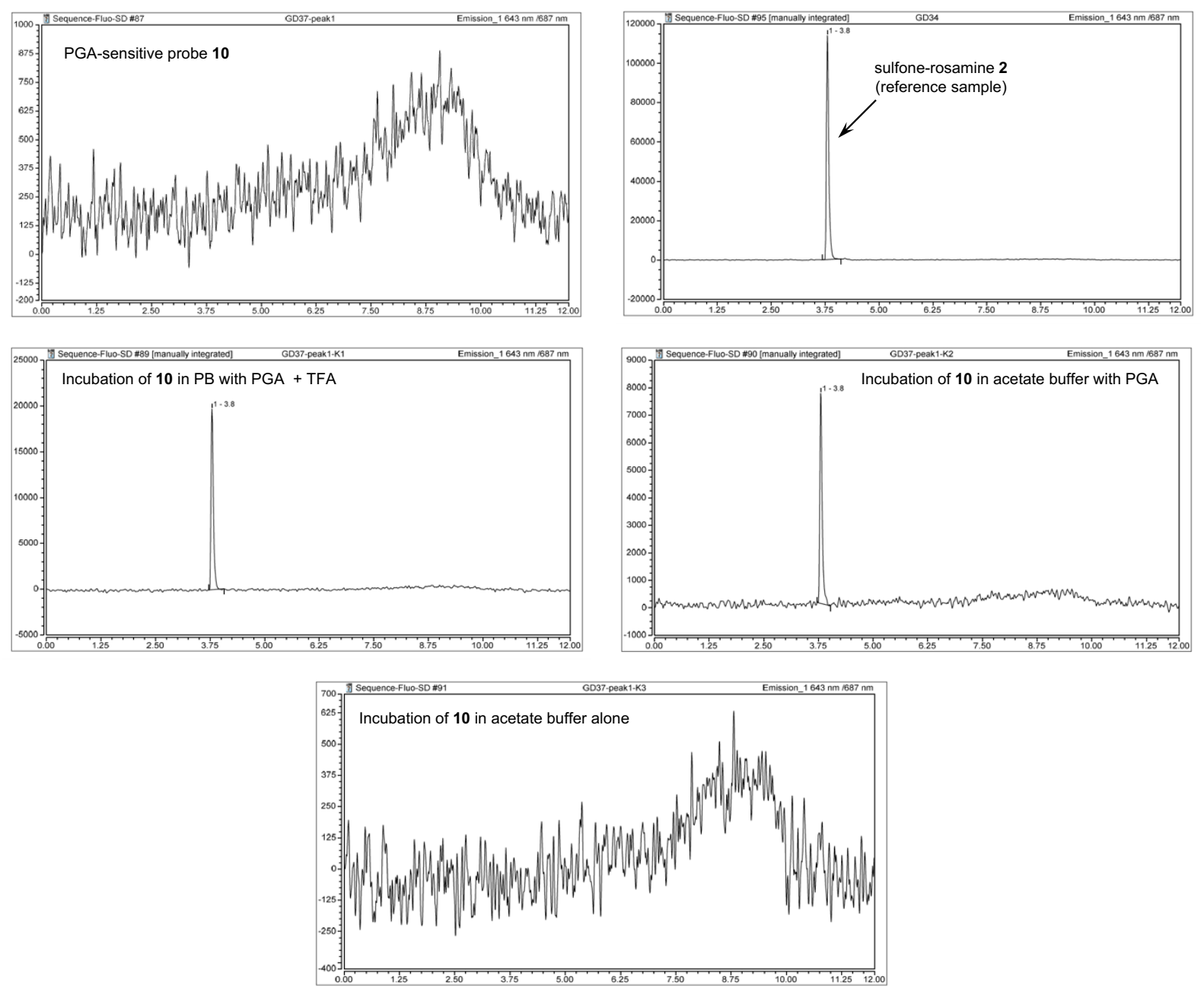

Fig. 8. RP-HPLC elution profiles (fluorescence detection, system $\mathrm{H}$ ) of enzymatic reaction mixtures from fluorescence assays (see Fig. 7). (Top left) fluorogenic probe 10 before incubation with PGA; (Middle left) fluorogenic probe 10 after incubation with PGA $\left(1 \mathrm{U}, 2 \mathrm{~h}, 37^{\circ} \mathrm{C}\right)$ in $\mathrm{PB}(\mathrm{pH} 7.4)$ and TFA; (Middle right) fluorogenic probe 10 after incubation with PGA $\left(1 \mathrm{U}, 2 \mathrm{~h}, 37^{\circ} \mathrm{C}\right)$ in acetate buffer (pH 3.5); (Bottom) blank= fluorogenic probe 10 incubated in acetate buffer alone; (Top right) Authentic sample of sulfone-rosamine $\mathbf{1 0}$.

\section{Conclusion}

In summary, sulfone analogs of 6-amino-3H-xanthen-3-imine and rosamine $\mathbf{2 M e} \mathbf{R G}$ were successfully synthesized for the first time. These NIR hetero-xanthene dyes are attractive fluorogenic scaffolds for the rapid construction of "smart" probes currently used in reactionbased detection strategies. Spectral characterization of these fluorophores in various solvent 
media has shed light on their poor aqueous stability, especially at physiological $\mathrm{pH}$. This is perfectly explained by the high electrophilicity of their meso-position which easily undergoes attack with water molecule (or hydroxide ion) to give a colorless and non-fluorescent benzhydrol/triaryl methanol derivative. The synthesis of unsymmetrical sulfonepyronin/rosamine dyes bearing both a strong electron-donating dialkylamino group and a remaining primary aniline may be a possible way to improve the aqueous stability of the sulfone-xanthene chromophore, by reducing the nucleophile sensitivity of its C-9 position. Indeed, Liu et al. did not observe hydration of $N, N, N^{\prime}, N^{\prime}$-tetramethyl-sulfone-rosamines (bearing a mono- or di-o-substituted aryl group as meso-substituent) in the $\mathrm{pH}$ range 2-8. To the best of our knowledge, the present study is the first and the only one which highlights the stability issue of hetero-xanthene-based fluorophores in aqueous media, particularly on those for which the 10-O atom is replaced by a strong electron-withdrawing group. This matter will need to be taken into consideration for future work devoted to long-wavelength heteroxanthenebased fluorophores and their bioanalytical applications. Gratifyingly, a good stability of fluorescent sulfone-rosamine $\mathbf{2}$ was observed under acidic buffered conditions. This feature, combined with the presence of fluorogenic centers (i.e., primary amino groups) within the sulfone-xanthene scaffold open the way for designing "smart" fluorescent probes for sensing and imaging within specific cellular acidic organelles (e.g., lysosomes). In this latter context, the development of "AND" molecular logic gates for the concomitant detection of two biological events (e.g., enzyme activation and $\mathrm{pH}$ changes) associated to a pathological state should be particularly interesting, for diagnostic purposes[78,80].

\section{Acknowledgements}

This work is supported by the CNRS, Université de Bourgogne and Conseil Régional de Bourgogne through the "Plan d'Actions Régional pour l'Innovation (PARI)" and the "Fonds Européen de Développement Régional (FEDER)" programs. G. D. gratefully acknowledges the Burgundy Franche-Comté region for his $\mathrm{Ph}$. D. grant. Financial support from Institut Universitaire de France (IUF), the Burgundy region ("FABER" programme, PARI Action 6, SSTIC 6 "Imagerie, instrumentation, chimie et applications biomédicales") and GDR CNRS "Agents d'Imagerie Moléculaire" (AIM) 2037 are also greatly acknowledged. The authors thank the "Plateforme d'Analyse Chimique et de Synthèse Moléculaire de l'Université de Bourgogne" (PACSMUB, http://www.wpcm.fr) for access to analytical instrumentation. COBRA lab (UMR 
CNRS 6014) and Iris Biotech company are warmly thanked for the generous gift of some chemical reagents used in this work. The authors also thank Dr. Sylvain Debieu and Dr. JeanAlexandre Richard (ICES, A*STAR, Singapore) for helpful discussion, M. Sylvain Orenga (bioMérieux, R\&D Microbiologie) for his interest in this work, M. Valentin Quesneau for the photography shown in Fig. 3, Miss Mare-José Penouilh (University of Burgundy, PACSMUB) for training in the use of $600 \mathrm{MHz}$ NMR spectrometer and M. Marcel Soustelle (University of Burgundy, ICMUB, UMR CNRS 6302) for elemental analysis.

\section{Appendix A. Supplementary data}

Supplementary data related to this article can be found online at 


\section{References}

[1] Beija M, Afonso CAM, Martinho JMG. Synthesis and applications of Rhodamine derivatives as fluorescent probes Chem. Soc. Rev. 2009; 38: 2410-33.

[2] Wright P, Staff Ub. Xanthene Dyes In: Kirk-Othmer Encyclopedia of Chemical Technology: John Wiley \& Sons, Inc (Ed.); 2014.

[3] Lavis LD. Teaching Old Dyes New Tricks: Biological Probes Built from Fluoresceins and Rhodamines Annu. Rev. Biochem. 2017; 86: 825-43.

[4] Kim HN, Lee MH, Kim HJ, Kim JS, Yoon J. A new trend in rhodamine-based chemosensors: application of spirolactam ring-opening to sensing ions Chem. Soc. Rev. 2008; 37: $1465-72$.

[5] Chen X, Pradhan T, Wang F, Kim JS, Yoon J. Fluorescent Chemosensors Based on Spiroring-Opening of Xanthenes and Related Derivatives Chem. Rev. 2012; 112: 1910-56.

[6] Tang Y, Lee D, Wang J, Li G, Yu J, Lin W, Yoon J. Development of fluorescent probes based on protection-deprotection of the key functional groups for biological imaging Chem. Soc. Rev. 2015; 44: 5003-15.

[7] Zhang R, Yan F, Huang Y, Kong D, Ye Q, Xu J, Chen L. Rhodamine-based ratiometric fluorescent probes based on excitation energy transfer mechanisms: construction and applications in ratiometric sensing RSC Adv. 2016; 6: 50732-60.

[8] Gonçalves MST. Fluorescent Labeling of Biomolecules with Organic Probes Chem. Rev. 2008; 109: 190-212.

[9] Zheng H, Zhan X-Q, Bian Q-N, Zhang X-J. Advances in modifying fluorescein and rhodamine fluorophores as fluorescent chemosensors Chem. Commun. 2013; 49: 429-47.

[10] Mao F, Leung W-Y, Haugland RP. Sulfonated xanthene derivatives synthesis and applications as fluorescent stains, Molecular Probes, Inc., WO9915517.

[11] Panchuk-Voloshina N, Haugland RP, Bishop-Stewart J, Bhalgat MK, Millard PJ, Mao F, Leung W-Y, Haugland RP. Alexa dyes, a series of new fluorescent dyes that yield exceptionally bright, photostable conjugates J. Histochem. Cytochem. 1999; 47: 1179-88.

[12] Berlier JE, Rothe A, Buller G, Bradford J, Gray DR, Filanoski BJ, Telford WG, Yue S, Liu J, Cheung C-Y, Chang W, Hirsch JD, Beechem JM, Haugland RP, Haugland RP. Quantitative comparison of long-wavelength Alexa Fluor dyes to Cy dyes: fluorescence of the dyes and their bioconjugates J. Histochem. Cytochem. 2003; 51: 1699-712.

[13] Leytus SP, Melhado LL, Mangel WF. Rhodamine-based compounds as fluorogenic substrates for serine proteinases Biochem. J. 1983; 209: 299-307.

[14] Leytus SP, Patterson WL, Mangel WF. New class of sensitive and selective fluorogenic substrates for serine proteinases. Amino acid and dipeptide derivatives of rhodamine Biochem. J. 1983; 215: 253-60.

[15] Sun Y-Q, Liu J, Lv X, Liu Y, Zhao Y, Guo W. Rhodamine-Inspired Far-Red to NearInfrared Dyes and Their Application as Fluorescence Probes Angew. Chem., Int. Ed. 2012; 51: 7634-6.

[16] Hong G, Antaris AL, Dai H. Near-infrared fluorophores for biomedical imaging Nat. Biomed. Eng. 2017; 1: 0010, DOI: 10.1038/s41551-016-0010.

[17] Liu J, Diwu Z, Leung W-Y, Lu Y, Patch B, Haugland RP. Rational design and synthesis of a novel class of highly fluorescent rhodamine dyes that have strong absorption at long wavelengths Tetrahedron Lett. 2003; 44: 4355-9.

[18] David E, Lejeune J, Pellet-Rostaing S, Schulz J, Lemaire M, Chauvin J, Deronzier A. Synthesis of fluorescent rhodamine dyes using an extension of the Heck reaction Tetrahedron Lett. 2008; 49: 1860-4.

[19] Romieu A, Tavernier-Lohr D, Pellet-Rostaing S, Lemaire M, Renard P-Y. Water solubilization of xanthene dyes by post-synthetic sulfonation in organic media Tetrahedron Lett. 2010; 51: 3304-8. 
[20] Chen J, Liu W, Zhou B, Niu G, Zhang H, Wu J, Wang Y, Ju W, Wang P. Coumarinand Rhodamine-Fused Deep Red Fluorescent Dyes: Synthesis, Photophysical Properties, and Bioimaging in Vitro J. Org. Chem. 2013; 78: 6121-30.

[21] Wang C, Wong KM-C. Selective $\mathrm{Hg}^{2+}$ Sensing Behaviors of Rhodamine Derivatives with Extended Conjugation Based on Two Successive Ring-Opening Processes Inorg. Chem. 2013; 52: 13432-41.

[22] Kamino S, Murakami M, Tanioka M, Shirasaki Y, Watanabe K, Horigome J, Ooyama Y, Enomoto S. Design and Syntheses of Highly Emissive Aminobenzopyrano-xanthene Dyes in the Visible and Far-Red Regions Org. Lett. 2014; 16: 258-61.

[23] Zhang M, Liu X, Yang M, Zheng S, Bai Y, Yang B-q. A series of deep red fluorescent dyes: synthesis, theoretical calculations and bioimaging applications Tetrahedron Lett. 2015; 56: $5681-8$.

[24] Niu G, Liu W, Zhou B, Xiao H, Zhang H, Wu J, Ge J, Wang P. Deep-Red and NearInfrared Xanthene Dyes for Rapid Live Cell Imaging J. Org. Chem. 2016; 81: 7393-9.

[25] Shirasaki Y, Okamoto Y, Muranaka A, Kamino S, Sawada D, Hashizume D, Uchiyama M. Fused-Fluoran Leuco Dyes with Large Color-Change Derived from Two-Step Equilibrium: iso-Aminobenzopyranoxanthenes J. Org. Chem. 2016; 81: 12046-51.

[26] Zhang M, Zheng S-t, Liu X-j, Long Y, Yang B-q. A series of novel NIR fluorescent dyes: Synthesis, theoretical calculations and fluorescence imaging applications in living cells Dyes Pigm. 2016; 125: 220-8.

[27] Zhao Y, Ren Y, Li H, Han T, Chen H, Guo W. A new far-red naphthorhodamine dye: Synthesis, fluorescent probe and bioimaging applications Dyes Pigm. 2016; 132: 255-61.

[28] Huang K, Jiao X, Liu C, Wang Q, Qiu X, He S, Zhao L, Zeng X. Synthesis of a novel $\pi$-extended hybrid rhodamine dye with far-red fluorescence emission and its application in bioimaging Dyes Pigm. 2017; 145: 561-9.

[29] Lei Z, Li X, Luo X, He H, Zheng J, Qian X, Yang Y. Bright, Stable, and Biocompatible Organic Fluorophores Absorbing/Emitting in the Deep Near-Infrared Spectral Region Angew. Chem., Int. Ed. 2017; 56: 2979-83.

[30] Liu C, Jiao X, Wang Q, Huang K, He S, Zhao L, Zeng X. A unique rectilinearly $\pi$ extended rhodamine dye with large Stokes shift and near-infrared fluorescence for bioimaging Chem. Commun. 2017; 53: 10727-30.

[31] Sun W, Guo S, Hu C, Fan J, Peng X. Recent Development of Chemosensors Based on Cyanine Platforms Chem. Rev. 2016; 116: 7768-817.

[32] Chen H, Dong B, Tang Y, Lin W. A Unique "Integration" Strategy for the Rational Design of Optically Tunable Near-Infrared Fluorophores Acc. Chem. Res. 2017; 50: 1410-22.

[33] Kolmakov K, Belov VN, Wurm CA, Harke B, Leutenegger M, Eggeling C, Hell SW. A Versatile Route to Red-Emitting Carbopyronine Dyes for Optical Microscopy and Nanoscopy Eur. J. Org. Chem. 2010: 3593-610.

[34] Koide Y, Urano Y, Hanaoka K, Terai T, Nagano T. Evolution of Group 14 Rhodamines as Platforms for Near-Infrared Fluorescence Probes Utilizing Photoinduced Electron Transfer ACS Chem. Biol. 2011; 6: 600-8.

[35] Kushida Y, Nagano T, Hanaoka K. Silicon-substituted xanthene dyes and their applications in bioimaging Analyst 2015; 140: 685-95.

[36] Ikeno T, Nagano T, Hanaoka K. Silicon-substituted Xanthene Dyes and Their Unique Photophysical Properties for Fluorescent Probes Chem. - Asian J. 2017; 12: 1435-46.

[37] Zhou X, Lesiak L, Lai R, Beck JR, Zhao J, Elowsky CG, Li H, Stains CI. Chemoselective Alteration of Fluorophore Scaffolds as a Strategy for the Development of Ratiometric Chemodosimeters Angew. Chem., Int. Ed. 2017; 56: 4197-200. 
[38] Chai X, Cui X, Wang B, Yang F, Cai Y, Wu Q, Wang T. Near-Infrared PhosphorusSubstituted Rhodamine with Emission Wavelength above $700 \mathrm{~nm}$ for Bioimaging Chem. - Eur. J. 2015; 21: 16754-8.

[39] Grzybowski M, Taki M, Yamaguchi S. Selective Conversion of $\mathrm{P}=\mathrm{O}-\mathrm{Bridged}$ Rhodamines into $\mathrm{P}=\mathrm{O}-\mathrm{Rhodols}$ : Solvatochromic Near-Infrared Fluorophores Chem. - Eur. J. 2017; 23: 13028-32.

[40] Zhou X, Lai R, Beck JR, Li H, Stains CI. Nebraska Red: a phosphinate-based nearinfrared fluorophore scaffold for chemical biology applications Chem. Commun. 2016; 52: 12290-3.

[41] Koide Y, Kawaguchi M, Urano Y, Hanaoka K, Komatsu T, Abo M, Terai T, Nagano T. A reversible near-infrared fluorescence probe for reactive oxygen species based on Terhodamine Chem. Commun. 2012; 48: 3091-3.

[42] Hirayama T, Mukaimine A, Nishigaki K, Tsuboi H, Hirosawa S, Okuda K, Ebihara M, Nagasawa H. Bismuth-rhodamine: a new red light-excitable photosensitizer Dalton Trans. 2017; 46: 15991-5.

[43] Detty MR, Prasad PN, Donnelly DJ, Ohulchanskyy T, Gibson SL, Hilf R. Synthesis, properties, and photodynamic properties in vitro of heavy-chalcogen analogues of tetramethylrosamine Bioorg. Med. Chem. 2004; 12: 2537-44.

[44] Liu J, Sun Y-Q, Zhang H, Shi H, Shi Y, Guo W. Sulfone-Rhodamines: A New Class of Near-Infrared Fluorescent Dyes for Bioimaging ACS Appl. Mater. Interfaces 2016; 8: $22953-$ 62.

[45] Chan J, Dodani SC, Chang CJ. Reaction-based small-molecule fluorescent probes for chemoselective bioimaging Nat. Chem. 2012; 4: 973-84.

[46] Grimm JB, Heckman LM, Lavis LD. The chemistry of small-molecule fluorogenic probes Prog. Mol. Biol. Transl. Sci. 2013; 113: 1-34.

[47] Chen X, Sun M, Ma H. Progress in spectroscopic probes with cleavable active bonds Curr. Org. Chem. 2006; 10: 477-89.

[48] Drake CR, Miller DC, Jones EF. Activatable optical probes for the detection of enzymes Curr. Org. Synth. 2011; 8: 498-520.

[49] Razgulin A, Ma N, Rao J. Strategies for in vivo imaging of enzyme activity: an overview and recent advances Chem. Soc. Rev. 2011; 40: 4186-216.

[50] Chen L, Li J, Du L, Li M. Strategies in the Design of Small-Molecule Fluorescent Probes for Peptidases Med. Res. Rev. 2014; 34: 1217-41.

[51] Singh K, Rotaru AM, Beharry AA. Fluorescent Chemosensors as Future Tools for Cancer Biology ACS Chem. Biol. 2018: in press, see DOI: 10.1021/acschembio.8b00014.

[52] Lin H-S, Paquette LA. A convenient method for determining the concentration of Grignard reagents Synth. Commun. 1994; 24: 2503-6.

[53] Kofron WG, Baclawski LM. A convenient method for estimation of alkyllithium concentrations J. Org. Chem. 1976; 41: 1879-80.

[54] Fulmer GR, Miller AJM, Sherden NH, Gottlieb HE, Nudelman A, Stoltz BM, Bercaw JE, Goldberg KI. NMR Chemical Shifts of Trace Impurities: Common Laboratory Solvents, Organics, and Gases in Deuterated Solvents Relevant to the Organometallic Chemist Organometallics 2010; 29: 2176-9.

[55] Mujumdar RB, Ernst LA, Mujumdar SR, Lewis CJ, Waggoner AS. Cyanine dye labeling reagents: sulfoindocyanine succinimidyl esters Bioconjugate Chem. 1993; 4: 105-11.

[56] Fu M, Xiao Y, Qian X, Zhao D, Xu Y. A design concept of long-wavelength fluorescent analogs of rhodamine dyes: replacement of oxygen with silicon atom Chem. Commun. 2008: 1780-2.

[57] Horváth P, Šebej P, Šolomek T, Klán P. Small-Molecule Fluorophores with Large Stokes Shifts: 9-Iminopyronin Analogues as Clickable Tags J. Org. Chem. 2015; 80: 1299-311. 
[58] Nie H, Qiao L, Yang W, Guo B, Xin F, Jing J, Zhang X. UV-assisted synthesis of longwavelength Si-pyronine fluorescent dyes for real-time and dynamic imaging of glutathione fluctuation in living cells J. Mater. Chem. B 2016; 4: 4826-31.

[59] Nie H, Jing J, Tian Y, Yang W, Zhang R, Zhang X. Reversible and Dynamic Fluorescence Imaging of Cellular Redox Self-Regulation Using Fast-Responsive Near-Infrared Ge-Pyronines ACS Appl. Mater. Interfaces 2016; 8: 8991-7.

[60] Wei L, Chen Z, Shi L, Long R, Anzalone AV, Zhang L, Hu F, Yuste R, Cornish VW, Min W. Super-multiplex vibrational imaging Nature 2017; 544: 465-70.

[61] Chen L, Wu D, Yoon J. Recent Advances in the Development of Chromophore-Based Chemosensors for Nerve Agents and Phosgene ACS Sens. 2018; 3: 27-43.

[62] A reaction-based probe for detecting 2-chloroethyl ethyl sulfide (2-CEES, mustard gas analog) whose the activation mechanism involves reaction of meso-position and aromatization to thiopyronin dye, was recently reported: Zhang Y, Lv Y, Wang X, Peng A, Zhang K, Jie X, Huang J, Tian Z. A Turn-On Fluorescent Probe for Detection of Sub-ppm Levels of a Sulfur Mustard Simulant with High Selectivity Anal. Chem. 2018; 90: 5481-8.

[63] Fukazawa A, Suda S, Taki M, Yamaguchi E, Grzybowski M, Sato Y, Higashiyama T, Yamaguchi S. Phospha-fluorescein: a red-emissive fluorescein analogue with high photobleaching resistance Chem. Commun. 2016; 52: 1120-3.

[64] Piao W, Tsuda S, Tanaka Y, Maeda S, Liu F, Takahashi S, Kushida Y, Komatsu T, Ueno T, Terai T, Nakazawa T, Uchiyama M, Morokuma K, Nagano T, Hanaoka K. Development of Azo-Based Fluorescent Probes to Detect Different Levels of Hypoxia Angew. Chem., Int. Ed. 2013; 52: 13028-32.

[65] Shin N, Hanaoka K, Piao W, Miyakawa T, Fujisawa T, Takeuchi S, Takahashi S, Komatsu T, Ueno T, Terai T, Tahara T, Tanokura M, Nagano T, Urano Y. Development of an Azoreductase-based Reporter System with Synthetic Fluorogenic Substrates ACS Chem. Biol. 2017; 12: 558-63.

[66] Tian Z, Tian B, Zhang J. Synthesis and characterization of new rhodamine dyes with large Stokes shift Dyes Pigm. 2013; 99: 1132-6.

[67] Hou J-T, Ren WX, Li K, Seo J, Sharma A, Yu X-Q, Kim JS. Fluorescent bioimaging of pH: from design to applications Chem. Soc. Rev. 2017; 46: 2076-90.

[68] Xu W, Zeng Z, Jiang J-H, Chang Y-T, Yuan L. Discerning the Chemistry in Individual Organelles with Small-Molecule Fluorescent Probes Angew. Chem., Int. Ed. 2016; 55: 1365899.

[69] Zhu H, Fan J, Du J, Peng X. Fluorescent Probes for Sensing and Imaging within Specific Cellular Organelles Acc. Chem. Res. 2016; 49: 2115-26.

[70] Yue Y, Huo F, Lee S, Yin C, Yoon J. A review: the trend of progress about $\mathrm{pH}$ probes in cell application in recent years Analyst 2017; 142: 30-41.

[71] Jiao X, Li Y, Niu J, Xie X, Wang X, Tang B. Small-Molecule Fluorescent Probes for Imaging and Detection of Reactive Oxygen, Nitrogen, and Sulfur Species in Biological Systems Anal. Chem. 2018; 90: 533-55.

[72] For instance, only 100 euros for 1000 units, see https://www.iris-biotech.de/de/ez50150.

[73] Yang Y, Chen Y, Aloysius H, Inoyama D, Hu L. Enzyme and Targeted Activation of Prodrugs In: Enzyme Technologies: Pluripotent Players in Discovering Therapeutic Agents, Hoboken, New Jersey: John Wiley \& Sons; 2014, p. 213-5.

[74] Gnaim S, Shabat D. Quinone-Methide Species, A Gateway to Functional Molecular Systems: From Self-Immolative Dendrimers to Long-Wavelength Fluorescent Dyes Acc. Chem. Res. 2014; 47: 2970-84.

[75] Alouane A, Labruère R, Le Saux T, Schmidt F, Jullien L. Self-Immolative Spacers: Kinetic Aspects, Structure-Property Relationships, and Applications Angew. Chem., Int. Ed. 2015; 54: 7492-509. 
[76] Roth ME, Green O, Gnaim S, Shabat D. Dendritic, Oligomeric, and Polymeric SelfImmolative Molecular Amplification Chem. Rev. 2016; 116: 1309-52.

[77] Guranda DT, Volovik TS, Sedas VK. pH stability of penicillin acylase from Escherichia coli Biochemistry (Moscow) 2004; 69: 1386-90.

[78] Romieu A. "AND" luminescent "reactive" molecular logic gates: a gateway to multianalyte bioimaging and biosensing Org. Biomol. Chem. 2015; 13: 1294-306.

[79] Erbas-Cakmak S, Kolemen S, Sedgwick AC, Gunnlaugsson T, James TD, Yoon J, Akkaya EU. Molecular logic gates: the past, present and future Chem. Soc. Rev. 2018; 47: 2228-48.

[80] Kolanowski JL, Liu F, New EJ. Fluorescent probes for the simultaneous detection of multiple analytes in biology Chem. Soc. Rev. 2018; 47: 195-208. 